\title{
Low-temperature-processed metal oxide electron transport layers for efficient planar perovskite solar cells
}

\author{
Jia-Xing Song, Xin-Xing Yin, Zai-Fang Li*i], Yao-Wen Li*(i)
}

Received: 7 August 2020/Revised: 10 September 2020/Accepted: 21 September 2020/Published online: 9 February 2021

(C) The Author(s) 2021

\begin{abstract}
As a promising photovoltaic technology, perovskite solar cells (pero-SCs) have developed rapidly over the past few years and the highest power conversion efficiency is beyond $25 \%$. Nowadays, the planar structure is universally popular in pero-SCs due to the simple processing technology and low-temperature preparation. Electron transport layer (ETL) is verified to play a vital role in the device performance of planar pero-SCs. Particularly, the metal oxide (MO) ETL with low-cost, superb versatility, and excellent optoelectronic properties has been widely studied. This review mainly focuses on recent developments in the use of low-temperature-processed MO ETLs for planar pero-SCs. The optical and electronic properties of widely used $\mathrm{MO}$ materials of $\mathrm{TiO}_{2}, \mathrm{ZnO}$, and $\mathrm{SnO}_{2}$, as well as the optimizations of these MO ETLs are briefly introduced. The commonly used methods for depositing MO ETLs are also discussed. Then, the applications of different MO ETLs on pero-SCs are reviewed. Finally, the challenge and future research of MO-based ETLs toward practical application of efficient planar peroSCs are proposed.
\end{abstract}

Keywords Perovskite solar cell; Electron transport layer; Metal oxide; Low temperature; Planar

\footnotetext{
J.-X. Song, X.-X. Yin, Z.-F. Li*

China-Australia Institute for Advanced Materials and

Manufacturing (IAMM), Jiaxing University, Jiaxing 314001,

China

e-mail: zaifang.li@zjxu.edu.cn

Y.-W. Li*

Laboratory of Advanced Optoelectronic Materials, College of Chemistry, Chemical Engineering and Materials Science,

Soochow University, Suzhou 215123, China

e-mail: ywli@suda.edu.cn
}

\section{Introduction}

To date, various photovoltaic technologies have been developed to harvest solar energy and generate electricity efficiently [1-3]. Among them, perovskite solar cell (pero$\mathrm{SC}$ ), a rising superstar, is considered as the most promising choice due to its low production cost, easy fabrication, and high-power conversion efficiency (PCE). The PCEs have been rapidly increasing at an unprecedented rate achieving a current world record of $25.2 \%$ through revolutionary improvements in the film crystal growth control, interface, and device engineering [4-6]. The high PCE of pero-SCs is attributed to the unique optoelectrical properties of perovskite, such as high light absorption ability, low exciton binding energy, long carrier diffusion length, and carrier lifetime [7-9].

In 2009, $\mathrm{MAPbBr}_{3}$ nanocrystalline was first introduced into a dye-sensitized solar cell (DSSC) as a sensitizer by Miyasaka's group and achieved a PCE of $3.8 \%$ [10]. However, this type of perovskite sensitized solar cells shows a poor stability due to the use of liquid electrolytes, which could gradually dissolve perovskite under the light irradiation. Since Park et al. remarkably introduced spiro-OMeTAD as a hole transporting material and assembled the standard solid-state pero-SC for the first time in 2012 [11], the solid-state pero-SC with mesoporous structure evolved into one of the most important device architectures. Unfortunately, the structure commonly needs a complicated process for depositing a compact layer followed by the mesoporous $\mathrm{TiO}_{2}$, where a high-temperature sintering process at more than $500{ }^{\circ} \mathrm{C}$ is unavoidable for improving their quality. The high temperature and complicated processes restrict the application of pero-SCs in flexible devices [12]. 
One representative way to fabricate pero-SCs with flexible compatibility is to develop the planar type peroSCs, which can simplify the fabrication process and reduce the processing temperature [13-15]. Since the perovskite material itself has a long carrier diffusion length and carrier lifetime, the carriers can effectively transport even if the mesoporous structure is absent [16]. Currently, typical planar pero-SCs can be structurally classified as regular (ni-p) and inverted (p-i-n) type, as shown in Fig. 1. In planar pero-SCs, electron transport layers (ETLs) play a crucial role in extracting and transporting the photogenerated electrons, and doing benefit to block holes and suppress the charge recombination [13-16]. Usually, both organic and inorganic n-type materials can be processed and serve as ETLs in pero-SCs. Organic ETLs show great merits of good solution process and flexibility. However, they are usually expensive and weak in the environmental, thermal, and mechanical stability [17-19]. Inorganic n-type materials, especially metal oxides (MOs) such as $\mathrm{TiO}_{2}, \mathrm{ZnO}$, and $\mathrm{SnO}_{2}$, are usually employed as ETLs with low-cost, low-temperature processability, superb versatility, great stability, and excellent optoelectronic properties [13-15, 20, 21]. Currently, many research efforts have been devoted toward developing and optimizing MO ETLs to pave the way for improvement and further application of pero-SCs [22, 23]. Although there have been some reviews on the progress of MO ETLs in pero-SCs [12, 24-26], few of them focused on the low-temperature-processed MO ETLs in planar pero-SCs systematically.

In this review, comments and discussions are offered firstly on the optical and electronic properties of widely used $\mathrm{MO}$ materials of $\mathrm{TiO}_{2}, \mathrm{ZnO}$, and $\mathrm{SnO}_{2}$, as well as the effect of element doping and constructing composites on MO ETLs. Then, the recent advances in the development of low-temperature-processed MO ETLs in planar peroSCs, various deposition technologies, and the application of MO ETLs are all surveyed. Finally, a perspective on the challenges and promising directions of low-temperatureprocessed MO ETLs is offered.

\section{MOs for ETL}

\subsection{Basic properties of MOs}

The device performance of pero-SCs largely depends on the properties of ETLs. Energy level of MO ETL is a key factor to be considered. The MO ETLs should have a good band alignment with the perovskite layer so that it can extract electrons easily and block holes effectively, as well as to increase the built-in potential [27]. Besides, a higher electron mobility of ETL is required to make more efficient charge transport and collection and thus reduce the charge recombination and the contact resistance at the interface. MOs with wide bandgap and small refractive index usually exhibit favorable transmittance, which could allow more sunlight to pass through and enhance light absorption by perovskite absorber in regular pero-SCs. In addition, MO ETLs on conductive substrate should be insensitive to ultraviolet light to guarantee the interface stability of ETLs and perovskite [28]. Meanwhile, high chemical stability is required for an outstanding MO ETL so that it can prevent gradual reaction with the adjacent perovskite or conductive electrode under certain conditions (Fig. 2a, b).

Among n-type $\mathrm{MOs}, \mathrm{TiO}_{2}, \mathrm{ZnO}$, and $\mathrm{SnO}_{2}$ are popular choices as ETLs for high-performance planar pero-SCs. Originated from DSSCs, $\mathrm{TiO}_{2}$ is one of the commonly used ETL in planar pero-SCs due to its wide bandgap and suitable energy levels compatible with perovskites [12]. In detail, the conduction band minimum (CBM) of $\mathrm{TiO}_{2}$ locates around $-4.1 \mathrm{eV}$ with a bandgap of $3.2 \mathrm{eV}$ for anatase, $3.1 \mathrm{eV}$ for brookite, and $3.0 \mathrm{eV}$ for rutile, respectively
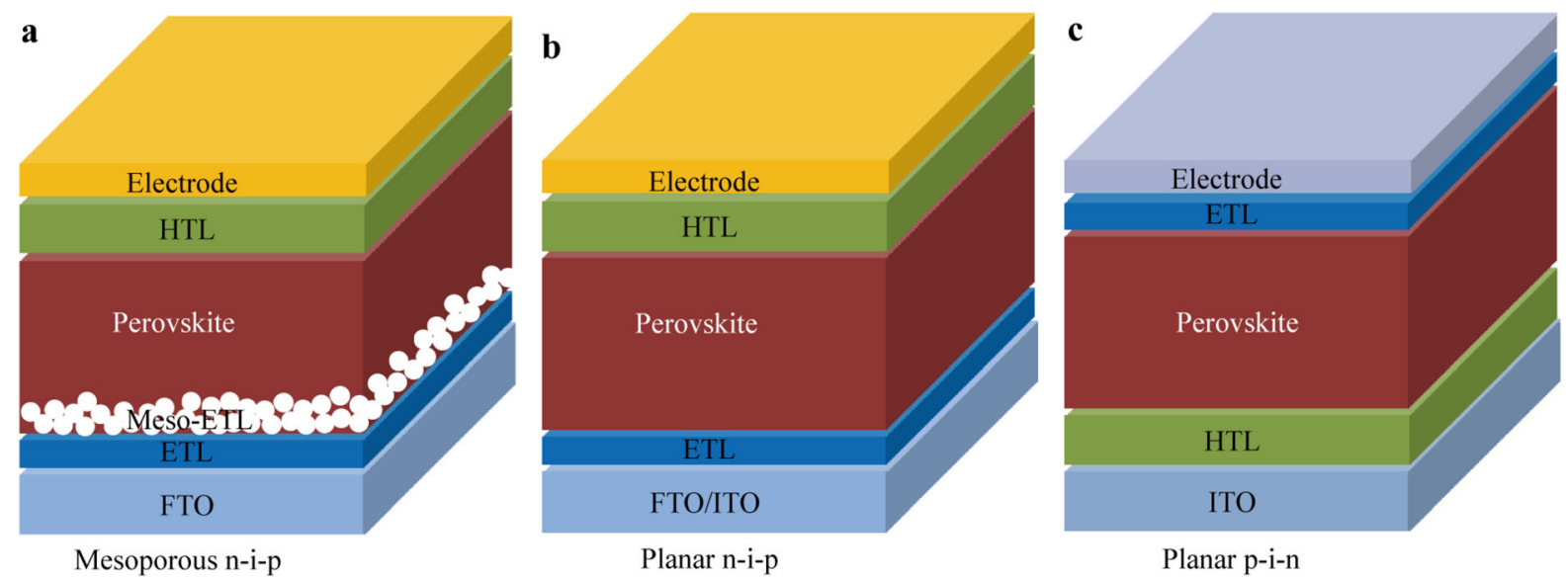

Fig. 1 Typical pero-SC structures: a mesoporous, b regular planar (n-i-p), and $\mathbf{c}$ inverted planar (p-i-n) 
$\mathbf{a}$

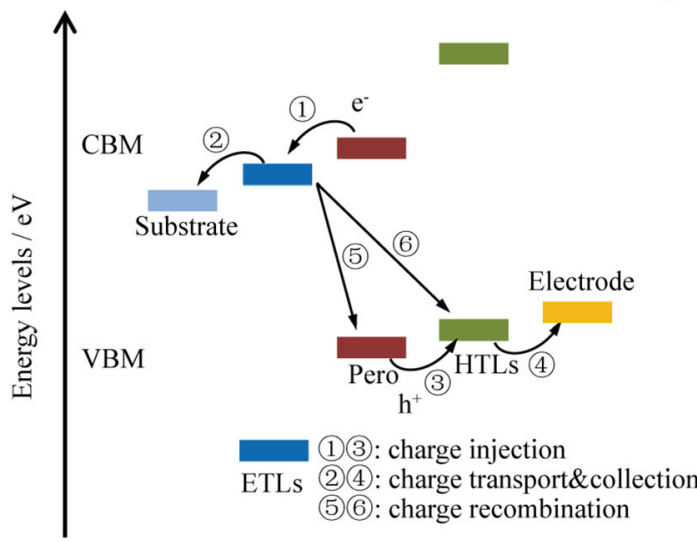

b

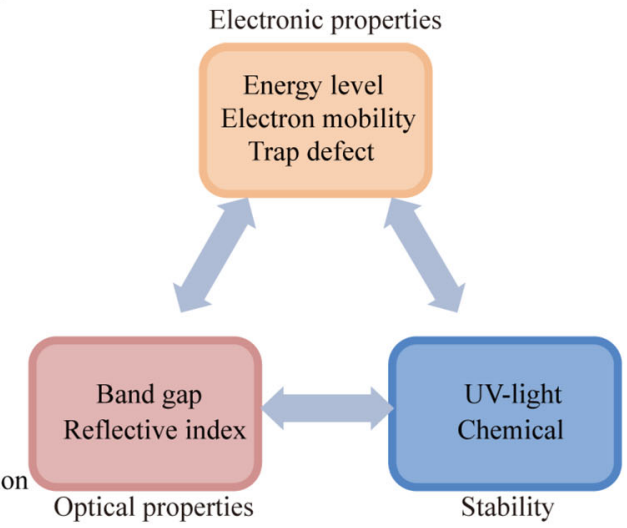

Fig. 2 a Schematic diagram of charge transfer process in typical regular pero-SCs based on MO ETLs; $\mathbf{b}$ major effect factors for MO ETLs

Table 1 Electronic properties of representative binary and ternary MO ETLs for planar pero-SCs

\begin{tabular}{|c|c|c|c|c|c|}
\hline ETL & $\mathrm{CBM} / \mathrm{eV}$ & $E_{\mathrm{g}} / \mathrm{eV}$ & Bulk mobility $/\left(\mathrm{cm}^{2} \cdot \mathrm{V}^{-1} \cdot \mathrm{S}^{-1}\right)$ & Refractive index & Refs. \\
\hline $\mathrm{TiO}_{2}$ & -4.1 & $3.0-3.2$ & $0.1-4$ & $2.4-2.5$ & {$[24,29,30]$} \\
\hline $\mathrm{ZnO}$ & -4.17 & $3.1-3.3$ & 205 & 2.1 & {$[25,32-34]$} \\
\hline $\mathrm{SnO}_{2}$ & -4.3 & $3.6-4.0$ & 240 & 2.0 & {$[24-26,36]$} \\
\hline $\mathrm{WO}_{x}$ & -4.5 & $2.6-3.1$ & $10-20$ & 1.95 & {$[40-42]$} \\
\hline $\mathrm{Nb}_{2} \mathrm{O}_{5}$ & -4.25 & $3.2-3.9$ & $0.2-0.4$ & $2.1-2.4$ & {$[43-45]$} \\
\hline $\mathrm{Cr}_{2} \mathrm{O}_{3}$ & -3.93 & 3.5 & $10^{-5}-1$ & $1.4-2.1$ & [46-48] \\
\hline $\mathrm{CeO}_{x}$ & -4.0 & 3.5 & 0.01 & $1.6-2.5$ & {$[25,49,50]$} \\
\hline $\mathrm{Fe}_{2} \mathrm{O}_{3}{ }^{*}$ & -4.5 & 2.2 & $0.01-0.1$ & $2.7-3.5$ & {$[51-53]$} \\
\hline $\mathrm{Zn}_{2} \mathrm{SnO}_{4}$ & -4.1 & 3.8 & $10-30$ & 2.0 & {$[54,55]$} \\
\hline $\mathrm{BaSnO}_{3}$ & -4.3 & 3.1 & 50 & 2.07 & {$[56-58]$} \\
\hline $\mathrm{TiZn}_{2} \mathrm{O}_{4}{ }^{*}$ & -4.13 & 3.29 & - & - & [59] \\
\hline $\mathrm{Ti}_{0.5} \mathrm{Fe}_{0.5} \mathrm{O}_{x}{ }^{*}$ & -4.08 & 2.65 & - & - & {$[60]$} \\
\hline
\end{tabular}

*Denoting high-temperature MO ETLs

$[29,30]$. Besides, it has a low refractive index of 2.4-2.5. However, the bulk electron mobility of $\mathrm{TiO}_{2}$ is relatively low with a range of $0.1-4 \mathrm{~cm}^{2} \cdot \mathrm{V}^{-1} \cdot \mathrm{s}^{-1}$, which makes a poor electron transport capability of $\mathrm{TiO}_{2}$ film [24]. Unfortunately, $\mathrm{TiO}_{2}$ is likely to degrade perovskite material under ultraviolet light due to its high catalytic activity [31]. $\mathrm{ZnO}$ is another widely used ETL material, which has attracted much attention as an alternative to $\mathrm{TiO}_{2}$. Similar to $\mathrm{TiO}_{2}$, ZnO has a favorable energy level structure ($4.17 \mathrm{eV}$ for CBM and $3.2 \mathrm{eV}$ for bandgap) as well as high transmittance in the visible light wavelength, but a much higher bulk electron mobility of over $200 \mathrm{~cm}^{2} \cdot \mathrm{V}^{-1} \cdot \mathrm{s}^{-1}$ [32-34]. Besides, $\mathrm{ZnO}$ has a good structural tuning ability at a nanoscale level and is easily to crystallize to form various nanostructures at low temperature, such as nanoparticles, nanorods, nanoflowers [24]. However, the thermal instability at the interface of $\mathrm{ZnO}$ /perovskite, stemming from the residual hydroxyl groups and/or acetate ligands on the $\mathrm{ZnO}$ surface, hampers its application [35]. Recently, $\mathrm{SnO}_{2}$ has attracted great attentions and been regarded as the most promising ETL material featuring with relatively deep CBM from -4.2 to $-4.5 \mathrm{eV}$, good band alignment with perovskite, as well as outstanding bulk electron mobility up to $240 \mathrm{~cm}^{2} \cdot \mathrm{V}^{-1} \cdot \mathrm{s}^{-1}[25,36]$. Besides, $\mathrm{SnO}_{2}$ has a small refractive index $(<2)$, a wide optical bandgap (3.6-4.0 eV), and a high transmittance over the whole visible spectra [25, 36]. Notably, $\mathrm{SnO}_{2}$ showed excellent chemical stability, UV-resistance properties, and less photocatalytic activity in comparison with $\mathrm{TiO}_{2}$ or other ETLs [36].

Although MOs demonstrate high potential as ETLs in pero-SCs, there are still some intrinsic problems such as trap defects, insufficient mobility, and mismatched energy levels. The above problems are not facilitated for highly 
efficient and stable pero-SCs, and thus, optimizing MO ETLs is necessary. Doping is a commonly used approach to tune the optical, electrical, and physicochemical properties of MOs. Generally, this method could not only passivate oxygen defects and reduce trap states at the surface of MOs but also lead to a better energy level alignment benefitting from the shift of CB [25]. Doping also could increase the mobility of MOs and dramatically improve the electron extraction and transport. Surface modification is regarded as an alternative to the doping approach, which can optimize the electronic properties and reduce defects of the MOs surface [37, 38]. In addition, the formation of novel composites is an effective approach to tune the properties of MOs via synergistic effect, such as straightly blending MOs with carbon materials or another binary MO with complementary properties. For example, by optimizing the size and concentration of graphene quantum dots (GQD), GQD-SnO ${ }_{2}$ films with higher conductivity, better film uniformity, and raised Fermi level were achieved, which remarkably contributed to electron transfer and device performance of regular pero-SCs [39]. The electronic

a
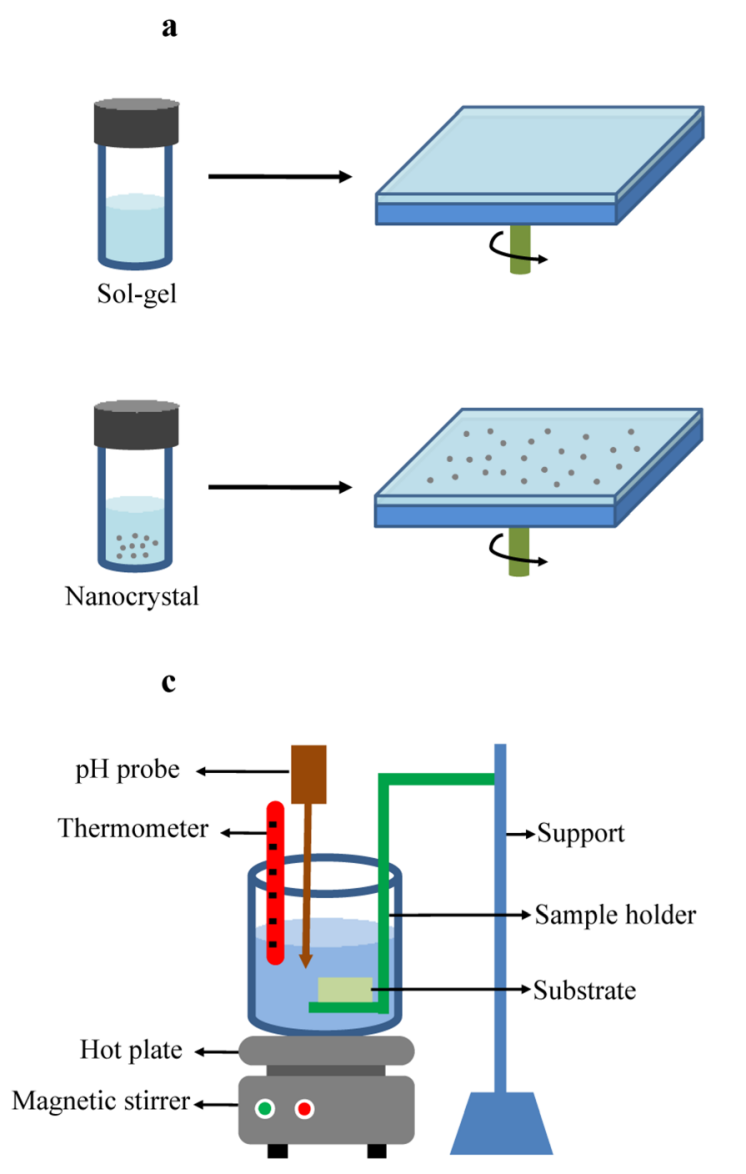

properties of representative binary and ternary MO ETLs for planar pero-SCs are shown in Table 1 [24-26, 29, 30, 32-34, 36, 40-60].

\subsection{Deposition methods of low-temperature-processed MO ETL}

The methods of depositing low-temperature MO ETLs on conductive substrate or perovskite absorber in pero-SCs are diverse. Here, the characteristics of universal methods are summarized.

\subsubsection{Solution process}

Solution process is usually employed to deposit low-temperature-processed ETLs by either thermal decomposition of metal salt precursors or direct synthesis of MO nanocrystals and nanocolloidals (Fig. 3a) [13, 61-64]. Regarding the thermal decomposition method, a metal salt precursor dissolved in the suitable solvent was deposited on the substrate by spin-coating or spray-coating methods, etc.
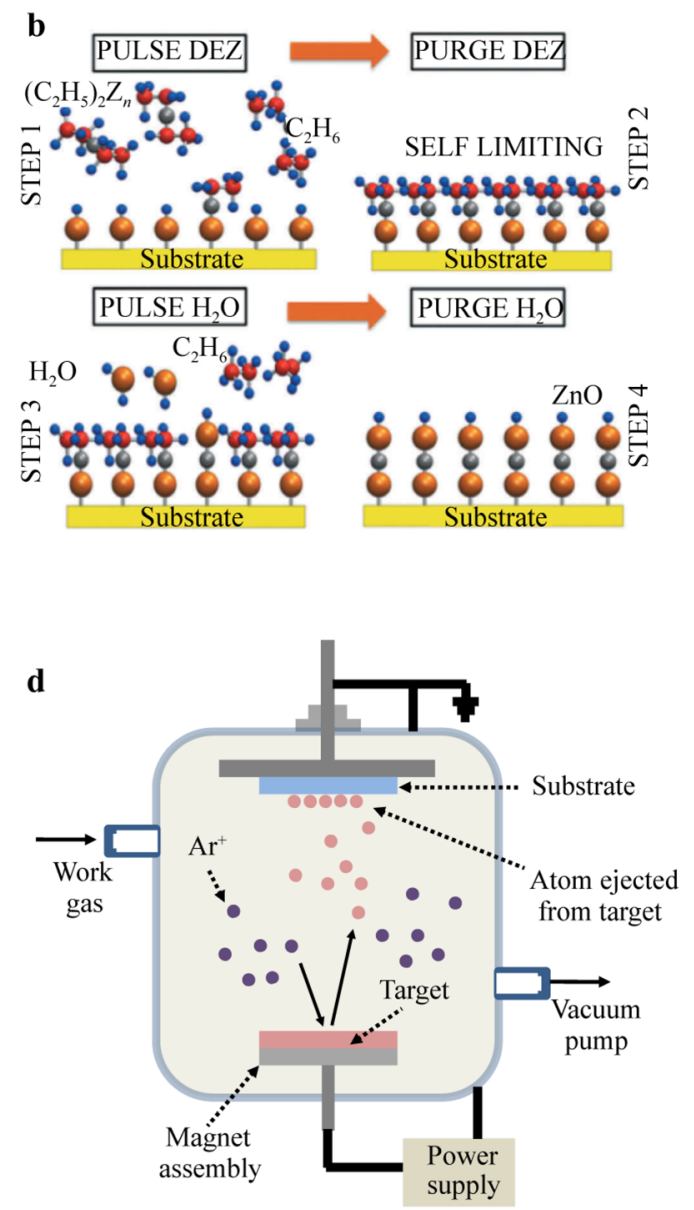

Fig. 3 Schematic illustration for typical deposition methods of MO ETLs: a solution process; b atomic layer deposition for ZnO film; c chemical bath deposition; and $\mathbf{d}$ magnetron sputtering 
Later, the as-deposited films were converted to desired MO layers by thermal annealing. The MO nanomaterials decouple the crystallization of oxide from the film-formation process, and the synthesized nano-sized solution can be directly deposited through many common methods, such as spin-coating, slot-die coating, and ink-jet printing. Among them, the slot-die coating and ink-jet printing present great potentials for mass production of MO ETLs. Solution process was widely used in a variety of lowtemperature-processed MO ETLs and high-performance planar pero-SCs due to both good crystallinity and less defects of deposited films. It should be noted that the ambient humidity and annealing temperature are critical to control the preparation of high-quality MO films during the thermal decomposition process $[25,36]$.

\subsubsection{Atomic layer deposition (ALD) process}

ALD is a key technology to finely control the film growth, which has been used to fabricate compact, uniform, and conformal thin films in semiconductor industry [65]. It is convenient to precisely control the film thickness and even suitable for film growth on rough substrates. A single ALD cycle consists of typical four steps: (1) exposure of the first precursor in the reactor chamber to form a layer on the substrate; (2) purge the excess first precursor and the byproducts; (3) exposure of the second precursor; and (4) purge or evacuation of the excess second precursor and byproducts. The ALD deposition process of $\mathrm{ZnO}$ is shown in Fig. 3b [24, 66]. Notably, ALD deposition is compatible with flexible substrate, the crystalline films can be achieved at a low growth temperature. So far, ALD method has been successfully applied in preparing low-temperature-processed MO ETLs, such as $\mathrm{TiO}_{2}$ [67], $\mathrm{ZnO}$ [68], and $\mathrm{SnO}_{2}$ [69] for high-performance pero-SCs. However, ALD method is high cost, time-consuming and sensitive to the purity of substrates, which may not be compatible for scalable production.

\subsubsection{Chemical bath deposition (CBD) process}

CBD is an extensively used technique to deposit semiconductor layers where the substrates are immersed into dilute solutions containing metal ions and sources of hydroxide or sulfide ions, as shown in Fig. 3c [25, 70]. It has been demonstrated to be suitable for the preparation of semiconductor layers in thin-film solar cells, such as CdS or $\mathrm{Zn}(\mathrm{S}, \mathrm{O}, \mathrm{OH})$ for $\mathrm{Cu}(\mathrm{In}, \mathrm{Ga}) \mathrm{Se}_{2}$ and $\mathrm{Cu}_{2} \mathrm{ZnSnS}_{4}$ [71, 72]. More importantly, recent reports have shown that $\mathrm{CBD}$ method can be successfully employed to prepare highly efficient MO ETLs such as $\mathrm{TiO}_{2}, \mathrm{ZnO}$, and $\mathrm{SnO}_{2}$ for planar pero-SCs with n-i-p structure [73, 74]. CBD method is suitable for low temperature and large-scale processing and has merits of low fabrication cost, easy growth adaptation as well as high reproducibility [25]. Nevertheless, the growing conditions referring to temperature, concentration, and $\mathrm{pH}$ of the solution have a great influence on the growth of thin films.

\subsubsection{Other deposition processes}

In addition to the deposition processes as mentioned above, there are also some other effective methods to prepare lowtemperature-processed MO ETLs according to the different physicochemical properties of materials. For example, electrochemical deposition (ED) is a common method to prepare high-quality MO thin films and is utilized in $\mathrm{TiO}_{2}$, $\mathrm{ZnO}$, and $\mathrm{SnO}_{2}$ ETLs of regular pero-SCs precedentedly [75-77]. The ED technique shows the merits of facile and fast deposition process as well as low-temperature preparation. And it can precisely control the quality of deposited layer forming good adhesion with substrate by adjusting the current density and depositing time [36]. Besides, several other physical deposition techniques such as magnetron sputtering (Fig. 3d) and E-beam evaporation were also utilized for MO ETLs deposition [78, 79]. These methods exhibit good potential in the fabrication of flexible devices because the MOs can crystallize along with the deposition on the substrates, which can successfully avoid post-annealing.

\section{Pero-SCs based on low-temperature-processed MO ETLs}

\section{$3.1 \mathrm{TiO}_{2}$}

Solution process is widely applied to deposit low-temperature $\mathrm{TiO}_{2}$ layer. Generally, the well-dispersed $\mathrm{TiO}_{2}$ nanoparticles (NPs) are a preferred approach for planar pero-SCs. Initially, Snaith et al. successfully fabricated a flat $\mathrm{TiO}_{x}$ film as ETL in a planar inverted pero-SC [13]. The all low-temperature-processed pero-SC realized a champion PCE approaching 10\%, and an over 6\% PCE on flexible polymer substrates. Subsequently, they synthesized $\mathrm{TiO}_{2}$ NPs by a nonaqueous approach using $\mathrm{TiCl}_{4}$, which delivered a crack-free $\mathrm{TiO}_{2}$ film [80]. With the addition of titanium diisopropoxidebis (acetylacetonate) (TiAcAc), the conductivity of $\mathrm{TiO}_{2}$ layer was significantly increased contributing to an improved PCE to $15.9 \%$, which demonstrated the feasibility of low-temperature process in regular pero-SCs. Conings et al. [81] introduced a low-temperature-processed $\mathrm{TiO}_{2}$ ETL deposited from an easy one-pot synthesis NP dispersion, customized for planar regular pero-SCs. The $\mathrm{TiO}_{2}$ layer requires a thermal treatment at only $135{ }^{\circ} \mathrm{C}$, making it 

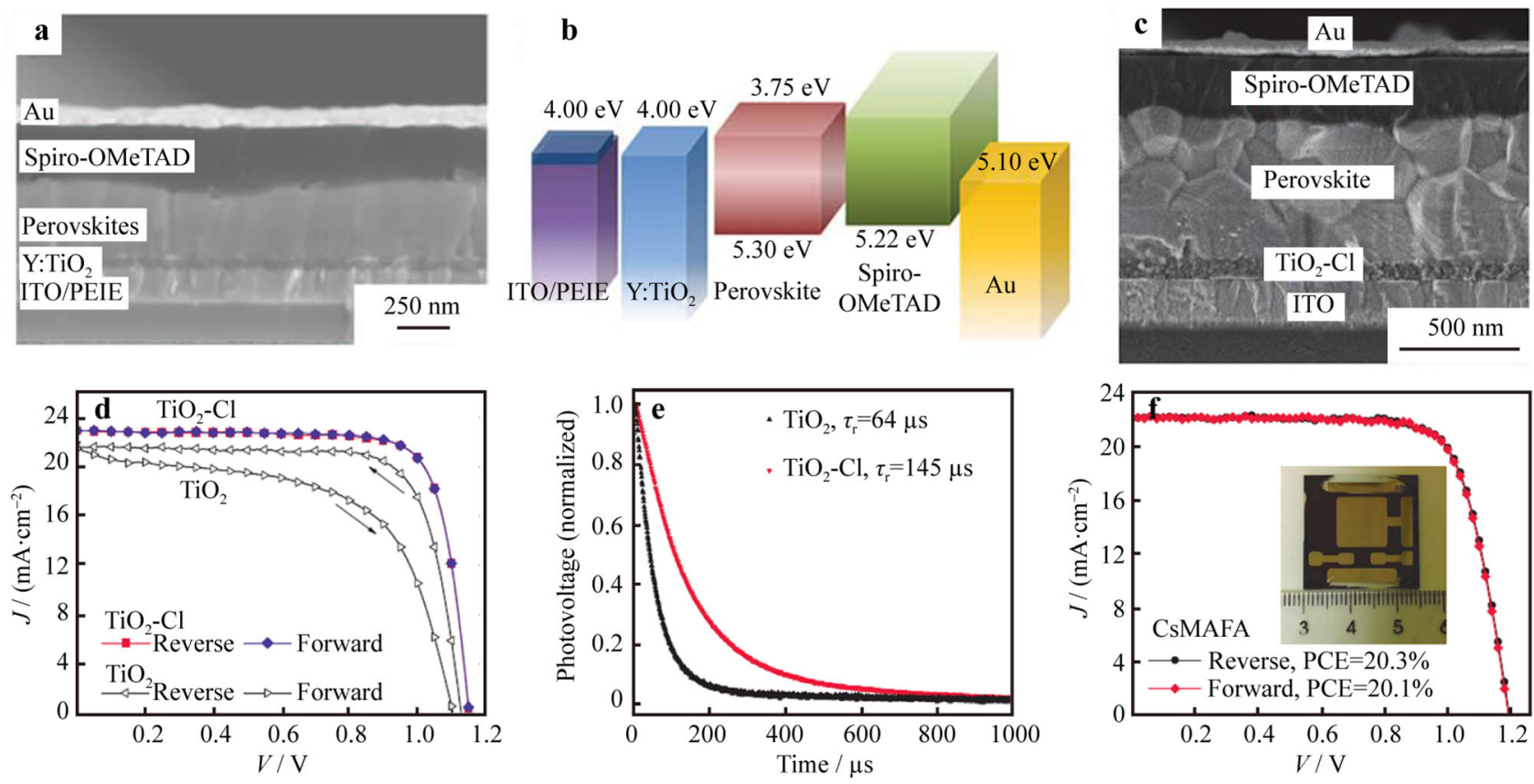

Fig. 4 a Cross-sectional SEM image of planar pero-SC based on Y: $\mathrm{TiO}_{2}$ ETL and $\mathbf{b}$ diagram of energy levels of pero-SC device. Reproduced with permission from Ref. [14]. Copyright 2014, The American Association for the Advancement of Science. c Device structure and crosssectional SEM image of planar pero-SC based on $\mathrm{TiO}_{2}-\mathrm{Cl}$ ETL; $\mathbf{d} J$ - $V$ curves of pero-SCs with $\mathrm{TiO}_{2}$ and $\mathrm{TiO}_{2}$-Cl as ETLs measured at reverse and forward scans; e Normalized transient photovoltage decay of pero-SCs with $\mathrm{TiO}_{2}$ and $\mathrm{TiO}_{2}-\mathrm{Cl}$ as ETLs $\left(\tau_{\mathrm{r}}\right.$, charge recombination lifetime); and $\mathbf{f} J-V$ curves of the best-performing large-area $\left(1.1 \mathrm{~cm}^{2}\right)$ CsMAFA pero-SC. The inset shows a photo of large-area device. Reproduced with permission from Ref. [82]. Copyright 2017, The American Association for the Advancement of Science

compatible with roll-to-roll fabrication on plastic foils. Almost simultaneously, Zhou et al. [14] reported a lowtemperature-processed ETL $\left(150{ }^{\circ} \mathrm{C}\right)$ by doping yttrium (Y) into $\mathrm{TiO}_{2}$ nanocrystals to manipulate carrier behavior and increase its conductivity (Fig. 4a, b). The Schottky barrier at the interface of $\mathrm{ITO} / \mathrm{TiO}_{2}$ was reduced by using PEIE and the Y-doped $\mathrm{TiO}_{2}$. The enhanced electron extraction and transport boosted the device performance up to $19.3 \%$. Recently, Tan and co-workers [82] found that the imperfect interfaces and charge recombination between $\mathrm{TiO}_{2}$ and perovskite could deteriorate device efficiency and stability in low-temperature planar peroSCs. As an alternative, they added chlorine $(\mathrm{Cl})$ to the $\mathrm{TiO}_{2}$ colloidal dispersion, resulting in a lower density of interfacial trap states and a stronger binding between $\mathrm{TiO}_{2}$ and perovskite. Based on the passivation strategy, the planar pero-SCs showed a PCE more than $20 \%$ and superior stability, as shown in Fig. 4c-f. More recently, Zhao et al. further increased the perovskite film quality that grown on the low-temperature $\mathrm{Cl}$-added $\mathrm{TiO}_{2} \mathrm{ETL}$ [83]. A CsCl-enhanced $\mathrm{PbI}_{2}$ precursor method by introducing $\mathrm{CsCl}$ into the $\mathrm{PbI}_{2}$ solution was reported to produce high-quality perovskite film via sequential deposition. By this approach, the device delivered a PCE exceeding $22 \%$, which demonstrated that $\mathrm{TiO}_{2} \mathrm{NP}$ ETL is a good candidate for planar pero-SCs.
Some other effective methods were also utilized to prepare low-temperature-processed $\mathrm{TiO}_{2}$ ETLs. Kim et al. [65] first applied the ALD technique to deposit an annealing-free $\mathrm{TiO}_{2}$ compact film for flexible planar peroSCs. Plasma enhanced ALD enabled to form a 20-nm-thick $\mathrm{TiO}_{x}$ compact layer on the plastic conductive substrate below $80{ }^{\circ} \mathrm{C}$. They presented highly bendable pero-SCs at a 1-mm bending radius, while the devices with the bending radii of $10 \mathrm{~mm}$ could withstand up to 1000 cycles retaining over 95\% of its initial PCE, as shown in Fig. 5a-c. Besides, Yella et al. [84] reported a CBD method to deposit a judiciously designed nanocrystalline $\mathrm{TiO}_{2}$ for application in the low-temperature-processed pero-SCs. The resulting rutile $\mathrm{TiO}_{2}$ could more efficiently extract photogenerated electrons from perovskite than the planar anatase $\mathrm{TiO}_{2}$ due to the increased interfacial area, thus resulting in impressive PCE of $13.7 \%$. Furthermore, with the CBD method, Liao et al. demonstrated a low-temperature $\left(70{ }^{\circ} \mathrm{C}\right)$ solution-processed $\mathrm{Mg}$-doped rutile $\mathrm{TiO}_{2}$ as ETL in efficient planar pero-SCs, while the doctor-bladed carbon was introduced as the counter electrode [73]. The optimized device yielded a champion PCE as high as $15.73 \%$. Magnetron sputtering is another interesting technique to deposit $\mathrm{TiO}_{2}$ ETL. Chen et al. [85] employed the radio frequency (RF) magnetron sputtering method to deposit $\mathrm{TiO}_{2}$ ETL on conductive substrate at low temperature for planar pero- 

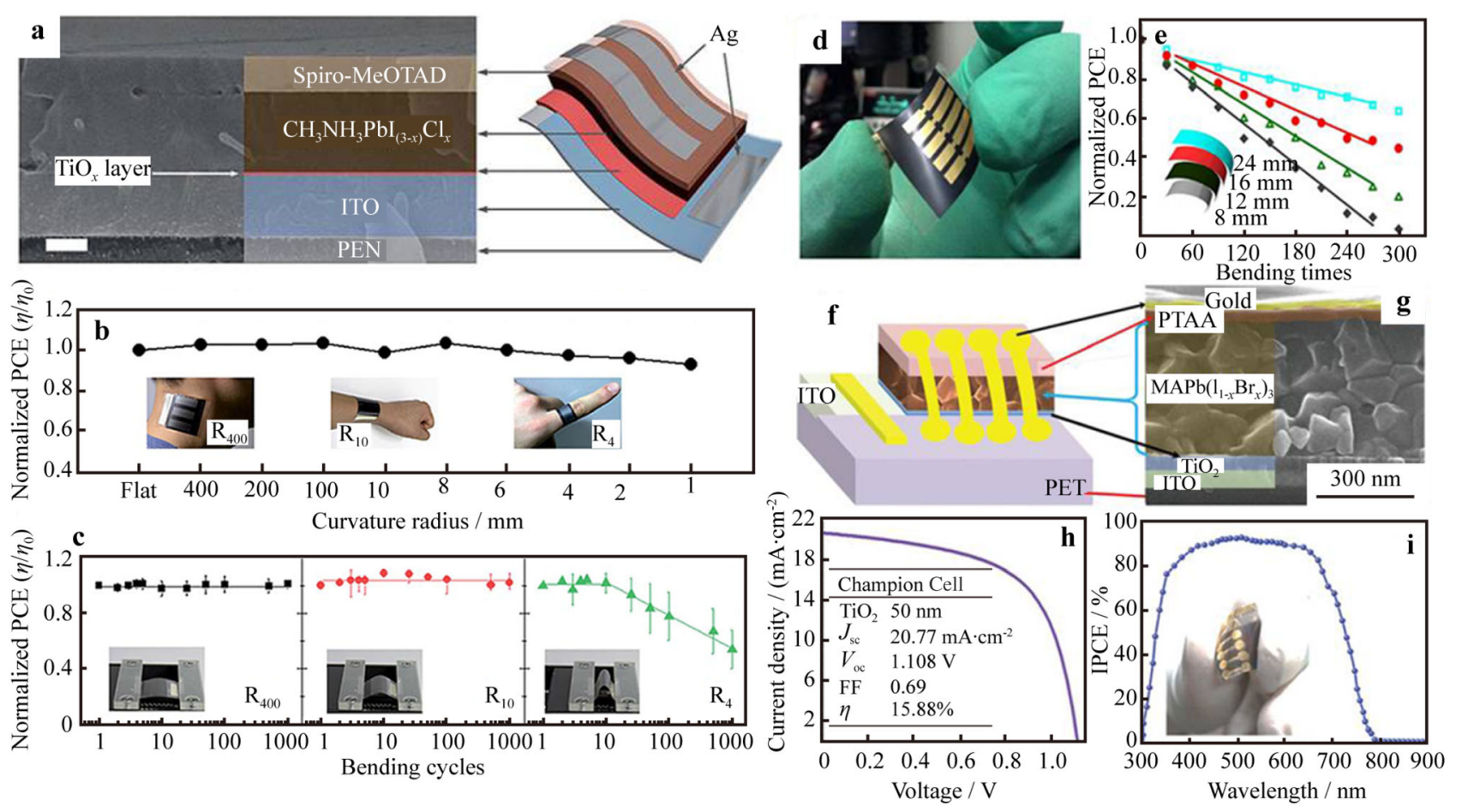

Fig. 5 a Cross-sectional SEM image of flexible planar pero-SC and schematic of device structure with ALD-TiO ; $_{2} \mathbf{b}$ normalized PCE of devices measured after bending substrate within a specified radius of $400 \mathrm{~mm}$ to $1 \mathrm{~mm}$ and (insets) real images attached on human neck, wrist, and finger corresponding to 400,10 , and $4 \mathrm{~mm}$ bending radii, respectively; c normalized PCE of flexible devices with radii of 400 , 10, and $4 \mathrm{~mm}$ as a function of bending cycles and (insets) real images taken during bending tests. Reproduced with permission from Ref. [65]. Copyright 2015, Royal Society of Chemistry. d Photograph of flexible pero-SC with $\mathrm{TiO}_{2}$ ETL by RF sputtering; e normalized PCE of flexible devices with radii of 24, 16, 12, and $8 \mathrm{~mm}$ as a function of times of bending cycles. Reproduced with permission from Ref. [85]. Copyright 2015, Springer Nature. f Schematic of device structure and $\mathbf{g}$ cross-sectional SEM image of planar flexible pero-SCs based on an RF sputtered TiO $\mathrm{ETL}_{2}$; $\mathbf{h}$-V $\mathrm{V}$ curve of champion pero-SC device and (inset table) corresponding solar cell parameters; and i IPCE spectrum of champion pero-SC device and (inset) real image of fabricated flexible pero-SC. Reproduced with permission from Ref. [86]. Copyright 2017, Royal Society of Chemistry

SCs. By controlling the thickness of $\mathrm{TiO}_{2}$ film, the flexible pero-SC with a PCE of $8.9 \%$ was achieved using this deposition technique (Fig. 5d, e). Yang et al. [78] further developed a sputtering technique for planar flexible peroSCs. The dense amorphous $\mathrm{TiO}_{2}$ ETL deposited at room temperature can offer faster electron transport and better electron extraction from perovskite, which facilitates to fabricate flexible device, achieving a $15.07 \%$ PCE. Recently, the compact and uniform $\mathrm{TiO}_{2}$ ETL by RFmagnetron sputtering method with an optimization was used to further improve the device performance to approximate $16 \%$ on flexible substrates, as shown in Fig. 5f-i [86]. Moreover, the resulted devices exhibited stable PCE for up to 200 bending cycles, demonstrating the superiority of the sputtering method.

\section{$3.2 \mathrm{ZnO}$}

ZnO NP solutions exhibit some unique advantages like simple and controllable synthesis process, and facile formation of low-temperature processed film, which has been extensively studied and used as the ETL in planar pero-
SCs. As for pero-SCs, ZnO NP films were firstly introduced by Liu and Kelly [20] in 2014, the ZnO NPs were synthesized through a solution method with $\mathrm{KOH}$ and $\mathrm{Zn}\left(\mathrm{CH}_{3} \mathrm{COO}\right)_{2} \cdot 2 \mathrm{H}_{2} \mathrm{O}$. Subsequently, they developed roomtemperature-processed $\mathrm{ZnO} \mathrm{NP}$ film as the compact ETL for planar regular pero-SCs, and the crystalline nature of NPs makes absent heating step possible. By optimizing the film thickness and surface roughness, the perovskite films with large crystallite size and a high PCE of $15.7 \%$ and $10.2 \%$ for rigid and flexible devices, respectively, were obtained. Hwang et al. [87] reported a fully slot-die-coated pero-SCs based on ZnO NP ETL fabricated with a homemade 3D printer under ambient conditions. As a result, the best PCE of $11.96 \%$ was realized (Fig. 6a-c), demonstrating the possibility of the low-cost mass production of pero-SCs. Meanwhile, Zhou et al. [88] reported a holetransporting layer and metal-electrode free planar pero-SC with a structure of $\mathrm{ZnO} /$ perovskite/carbon. By using this unique structure, the mechanical strength of flexible devices can also be significantly improved. To address the thermal instability issue of $\mathrm{ZnO}$-based pero-SCs, Song et al. [89] used commercial $\mathrm{ZnO}$ NPs to prepare low- 

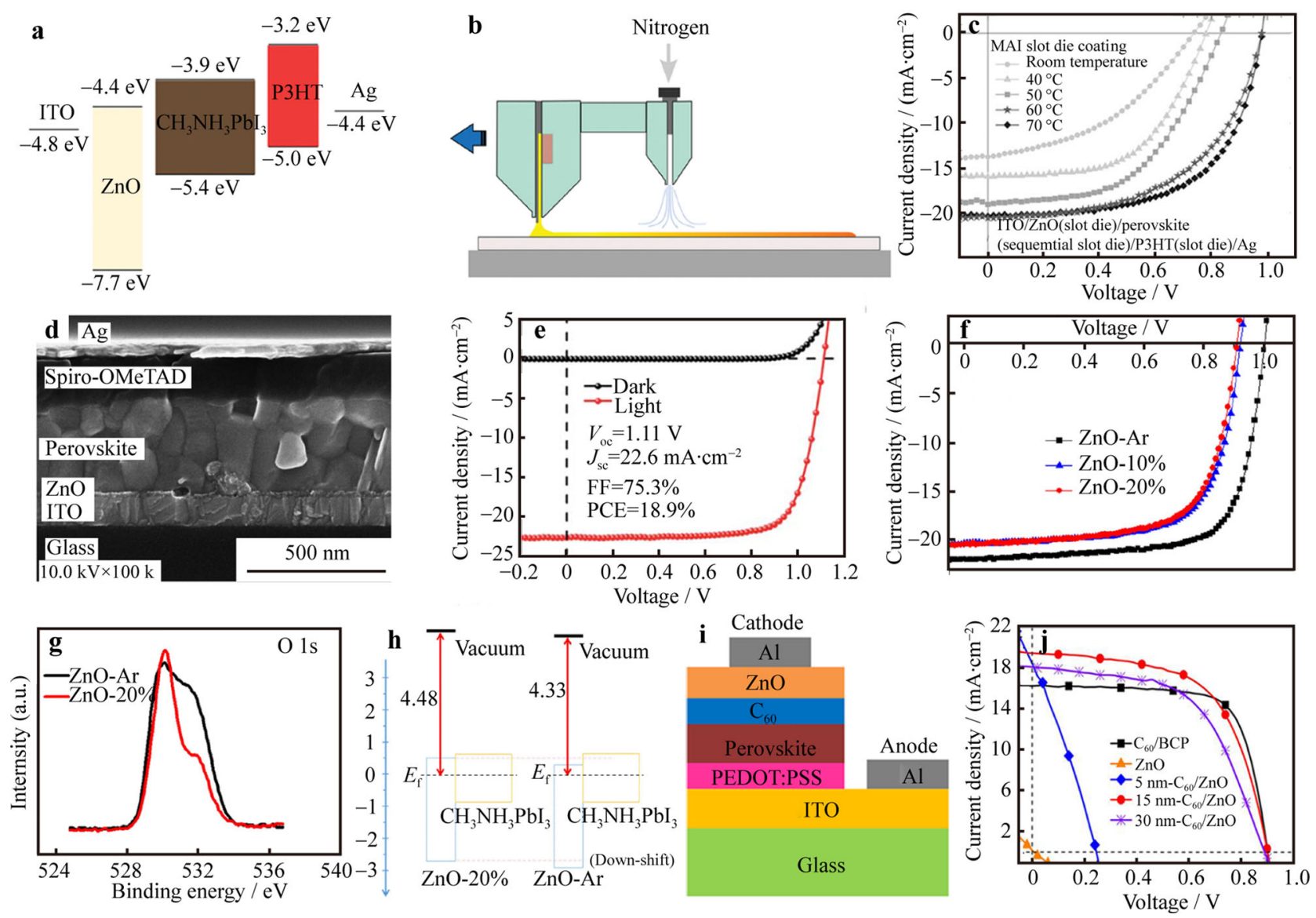

Fig. 6 a Energy level diagram of fully slot-die coated pero-SC; b schematic illustration of slot-die coating with a gas-quenching process for preparation of $\mathrm{PbI}_{2} ;$ c $J-V$ characteristics for highest-performing pero-SCs under various processing-temperatures of MAI slot-die coating. Reproduced with permission from Ref. [87]. Copyright 2015, John Wiley and Sons. d Cross-sectional SEM image of planar pero-SC device based on triple cation perovskite and ZnO ETL; e photocurrent density-voltage characteristic of best-performing device and dark $J$ - $V$ curve. Reproduced with permission from Ref. [90]. Copyright 2017, Royal Society of Chemistry. f $J$ - $V$ curves of pero-SCs based on ZnO ETL prepared by sputtering under working gas of pure $\mathrm{Ar}(\mathrm{ZnO}-\mathrm{Ar})$ and $\mathrm{O}_{2} / \mathrm{Ar}$ mixture $(\mathrm{ZnO}-10 \%$ and $\mathrm{ZnO}-20 \%)$; g XPS spectra of $\mathrm{ZnO}-\mathrm{Ar}$ and $\mathrm{ZnO}-20 \%$ films, and $\mathbf{h}$ illustration of frontier orbitals energy levels. Reproduced with permission from Ref. [96]. Copyright 2015, Springer Nature. i Device structure of inverted pero-SC based on sputtered ZnO ETL, and $\mathbf{j} J$ - $V$ characteristics of pero-SCs with various ETLs for comparison. Reproduced with permission from Ref. [98]. Copyright 2015, AIP Publishing

temperature ETL for pero-SCs by spin-coating and employed $\mathrm{HC}\left(\mathrm{NH}_{2}\right)_{2}{ }^{+}$instead of $\mathrm{CH}_{3} \mathrm{NH}_{3}{ }^{+}$to synthesize the perovskite via sequential deposition method. Upon optimization, the $\mathrm{ZnO}-\mathrm{FAPbI}_{3}$ planar structure demonstrated a PCE as high as $16.1 \%$, and the thermostability of the perovskite film on $\mathrm{ZnO}$ was substantially improved with $\mathrm{FAPbI}_{3}$ due to the basically robust nature of FA compared with $\mathrm{MA}$ in $\mathrm{MAPbI}_{3}$. Further, when replacing $\mathrm{FAPbI}_{3}$ with triple cation perovskite, a stable light absorber prepared with a one-step deposition method could be realized based on the same ZnO NP ETL, and the pero-SCs achieved the highest PCE of $18.9 \%$ accompanying with excellent environment durability and photostability (Fig. 6d, e) [90]. Recently, an ultrasonic-assisted method was reported, and a more transparent $\mathrm{ZnO}$ NP solution was obtained, which facilitated to form a denser and more uniform $\mathrm{ZnO}$ film. In this research, an aging step of $\mathrm{ZnO}$ film in air at room temperature was also introduced to improve the thermal stability between $\mathrm{ZnO}$ and $\mathrm{MAPbI}_{3}$. Under the synergistic effect of high-quality $\mathrm{ZnO}$ and perovskite films, the degradation of device was effectively suppressed, showing a high stability even though exposed in air for 45 days [91]. Yang et al. reported a low temperature and aqueous solution-processed route using an ammine-hydroxo zinc complex solution, $\left[\mathrm{Zn}\left(\mathrm{NH}_{3}\right)_{x}\right](\mathrm{OH})_{2}$, to prepare the $\mathrm{ZnO}$ ETLs for pero-SCs [92]. As a result, the processing temperature of $\mathrm{ZnO}$ layer can be reduced to $150{ }^{\circ} \mathrm{C}$, and the related device with a n-i-p structure exhibited an increased open-circuit voltage of $1.07 \mathrm{~V}$. When implanted ZnO ETL in the p-i-n structure, the lowtemperature $\mathrm{ZnO}$ NPs on top of perovskite film enabled the p-i-n structure pero-SCs to have both inorganic HTL and ETL, which delivered a PCE of $16.1 \%$ and significantly improved device stability compared with the pero-SCs 
using organic HTL and ETL [93]. Because the top ZnO layer could effectively prevent elemental interdiffusion between perovskite and metal electrode. Similarly, Savva et al. [94] incorporated the low-temperature-processed aluminum-doped $\mathrm{ZnO}$ (AZO) as ETL in inverted pero-SCs. AZO can further optimize the characteristics of MO providing suitable energy levels for carrier selectivity, neutralizing the presence of pinholes, and providing intimate interfaces, thus contributing to the increased PCE, improved reliability, and stability of pero-SCs.

As for other deposition methods, Lee et al. [95] developed the compact $\mathrm{ZnO}$ films by ALD method under a temperature of $80^{\circ} \mathrm{C}$ as the ETL of planar regular pero$\mathrm{SCs}$, where systematic investigation about the effect of $\mathrm{ZnO}$ film thickness on the pero-SCs performance was carried out. By this method, Yuan et al. realized a PCE of $13.1 \%$ [68]. They found that the ALD-based compact $\mathrm{ZnO}$ layer could facilitate the growth of $\mathrm{CH}_{3} \mathrm{NH}_{3} \mathrm{PbI}_{3}$ when the precursor containing chloridion at room temperature. Mathews et al. employed both a $\mathrm{ZnO}$ compact film formed by electro-deposition method and a $\mathrm{ZnO}$ nanorod film grown by CBD method as the ETL for pero-SCs, achieving the fabrication of low temperature, solution-processed and flexible pero-SCs [74]. Meanwhile, Zhang and Pauportè [76] applied the electro-deposition method to deposit $\mathrm{ZnO}$ ETL at low temperature for pero-SC application. The $\mathrm{ZnO}$ and $\mathrm{TiO}_{2}$ ETLs and their influence on the preparation of $\mathrm{CH}_{3} \mathrm{NH}_{3} \mathrm{PbI}_{3}$ by either "one-step" or "two-step" techniques were investigated and compared. The results indicated that the best device efficiency of $15 \%$ could be achieved by combining a low-overvoltage electro-deposited $\mathrm{ZnO}$ layer and a "one-step" route deposited perovskite layer. Magnetron sputtering technology is also a popular method to fabricate $\mathrm{ZnO}$ ETL. Tseng et al. [96] studied the influence of RF sputtering parameters on the $\mathrm{ZnO}$ film quality. They found that the electric and electronic properties of $\mathrm{ZnO}$ film were greatly affected by the oxygen vacancies which could be controlled by adjusting the ratio of working gases $\left(\mathrm{Ar}\right.$ and $\left.\mathrm{O}_{2}\right)$ during the sputtering process (Fig. $6 \mathrm{f}-\mathrm{h}$ ). The resulting regular planar pero-SC based on $\mathrm{ZnO}$ fabricated under Ar working gas achieved the highest PCE up to $15.9 \%$, demonstrating that sputtering was one of the excellent techniques to prepare $\mathrm{ZnO}$ ETL with controllable properties. By using the similar method, they also successfully prepared the high quality, fully covered Al-doped $\mathrm{ZnO}$ (AZO) film on ITO substrate [97], which showed a higher conductivity, better band matching with $\mathrm{MAPbI}_{3}$ and higher acid resistance than $\mathrm{ZnO}$. Therefore, pero-SC based on this AZO ETL efficiently promoted the device performance. In the pero-SCs with inverted structure, room-temperature RF-sputtered $\mathrm{ZnO}$ was also considered as a feasible choice of ETL. Lai et al. [98] introduced a $\mathrm{C}_{60}$ interlayer between perovskite and sputtered $\mathrm{ZnO}$ layers for protection to prevent the sputtering damages on the perovskite layer, which could increase the device performance, as shown in Fig. 6i, j.

\section{$3.3 \mathrm{SnO}_{2}$}

$\mathrm{SnO}_{2}$ is an intrinsic n-type semiconductor with unique advantages, including natural abundance, nontoxic, high electron mobility, good stability, and high transparency, which present tremendous potential as ETL materials in planar pero-SCs. Among various deposition methods, lowtemperature solution process, including thermal decomposition of Sn-based precursors (sol-gel approach) and direct spin-coating of $\mathrm{SnO}_{2} \mathrm{NP}$ solutions, is the most widely used method for preparing $\mathrm{SnO}_{2}$ films. For sol-gel approach, Sn-based salts such as $\mathrm{SnCl}_{2}, \mathrm{SnCl}_{4}$, or their hydrate $\mathrm{SnCl}_{2} \cdot 2 \mathrm{H}_{2} \mathrm{O}$ and $\mathrm{SnCl}_{4} \cdot 5 \mathrm{H}_{2} \mathrm{O}$ are used to synthesize $\mathrm{SnO}_{2}$ films after thermal annealing in ambient air. In 2015, Ke et al. [63] adopted a $\mathrm{SnCl}_{2} \cdot 2 \mathrm{H}_{2} \mathrm{O}$ as precursor to synthesize $\mathrm{SnO}_{2}$ by thermal annealing in air at $180{ }^{\circ} \mathrm{C}$ for $1 \mathrm{~h}$ (Fig. 7a). After a UV-ozone treatment for $15 \mathrm{~min}$, the perovskite film could be well grown on it showing a champion PCE of $17.21 \%$. By using the similar method, Zuo et al. [99] reported a $\mathrm{SnO}_{2}$-based planar pero-SCs with an impressive PCE of $20.23 \%$ after modifying perovskite with a polymer template. To reduce the thermal decomposition temperature, Dong et al. [100] proposed a new sol-gel route by introducing atmosphere $\mathrm{O}_{2}$ and $\mathrm{H}_{2} \mathrm{O}$ by refluxing, which greatly promoted the oxidation and hydrolysis of $\mathrm{SnCl}_{2} \cdot 2 \mathrm{H}_{2} \mathrm{O}$ in alcohol solution. As a result, the $\mathrm{SnO}_{2}$ film could be reduced below $80{ }^{\circ} \mathrm{C}$. The n-i-p structured devices based on this $\mathrm{SnO}_{2}$ ETL realized PCEs of $19.2 \%$ and $16.11 \%$ on rigid and flexible substrates, respectively. Subbiah et al. [101] employed a low-power $\mathrm{N}_{2}$ RF plasma to activate the precursor film at room temperature. The high-energy UV photons generated from $\mathrm{N}_{2}$ plasma facilitated the break of alkoxy and hydroxyl groups, leading to the formation of the metal-oxide-metal framework. The pero-SCs based on $\mathrm{N}_{2}$ plasma-treated $\mathrm{SnO}_{2}$ gave a PCE of $20.3 \%$ on rigid substrates. This method was also used to fabricate flexible pero-SCs on PET substrates showing a champion PCE of $18.1 \%$, and $90 \%$ of its initial efficiency could be retained after 1000 bending cycles (Fig. 7g-i).

In comparison, the $\mathrm{SnO}_{2}$ NPs are prepared before deposition, and therefore, the high-temperature decomposition process can be avoided. In 2015, Song et al. [64] dispersed the commercial $\mathrm{SnO}_{2}$ NPs (ca. 22-43 nm) in butanol and prepared the $\mathrm{SnO}_{2} \mathrm{NP}$ thin-film by spin-coating as the ETL to fabricate low-temperature-processed pero-SCs. However, the produced $\mathrm{SnO}_{2}$ NP films were not very uniform, and the n-i-p structured devices showed a best PCE of $13.0 \%$. Further, You et al. used the 

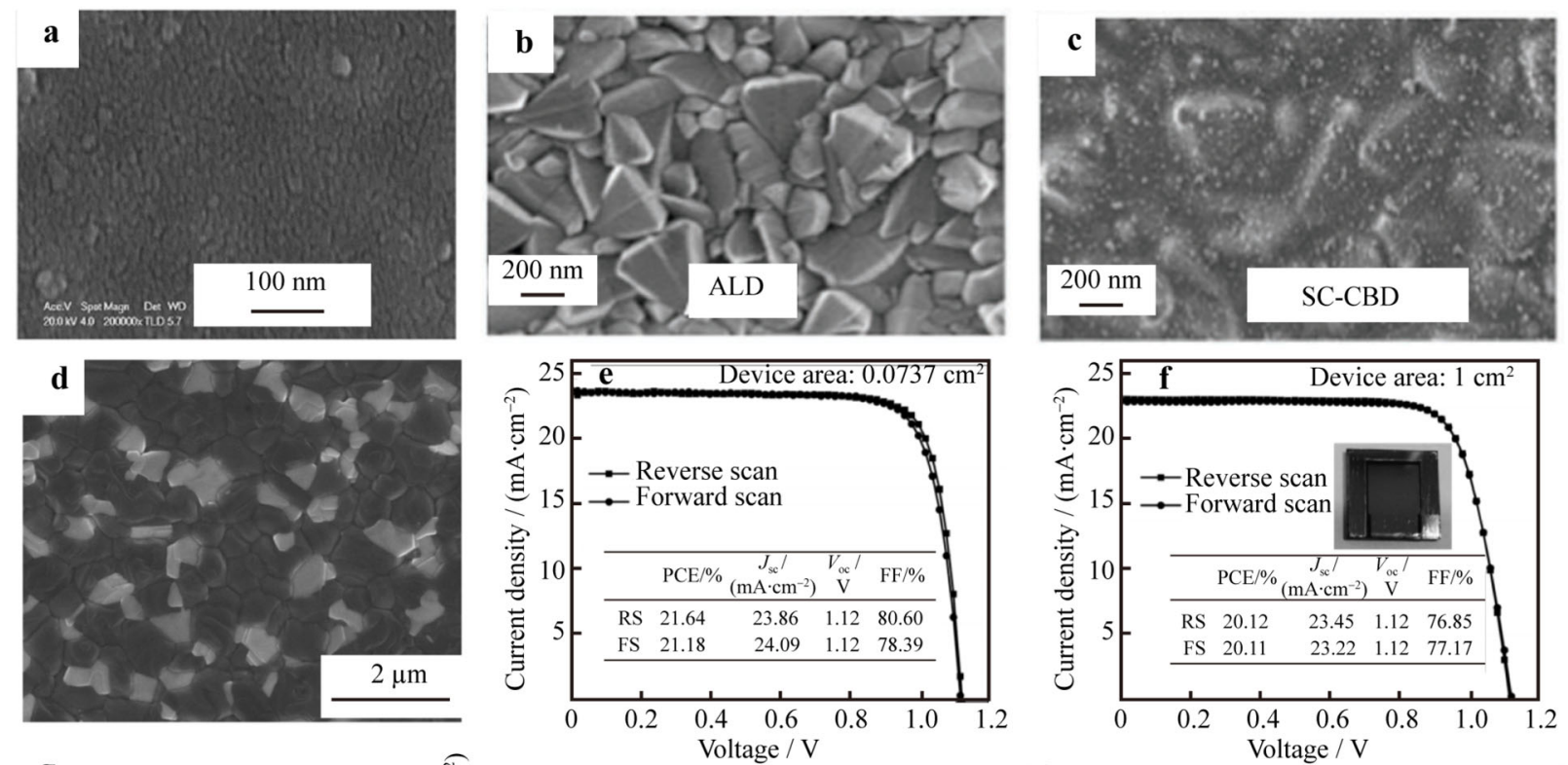

g
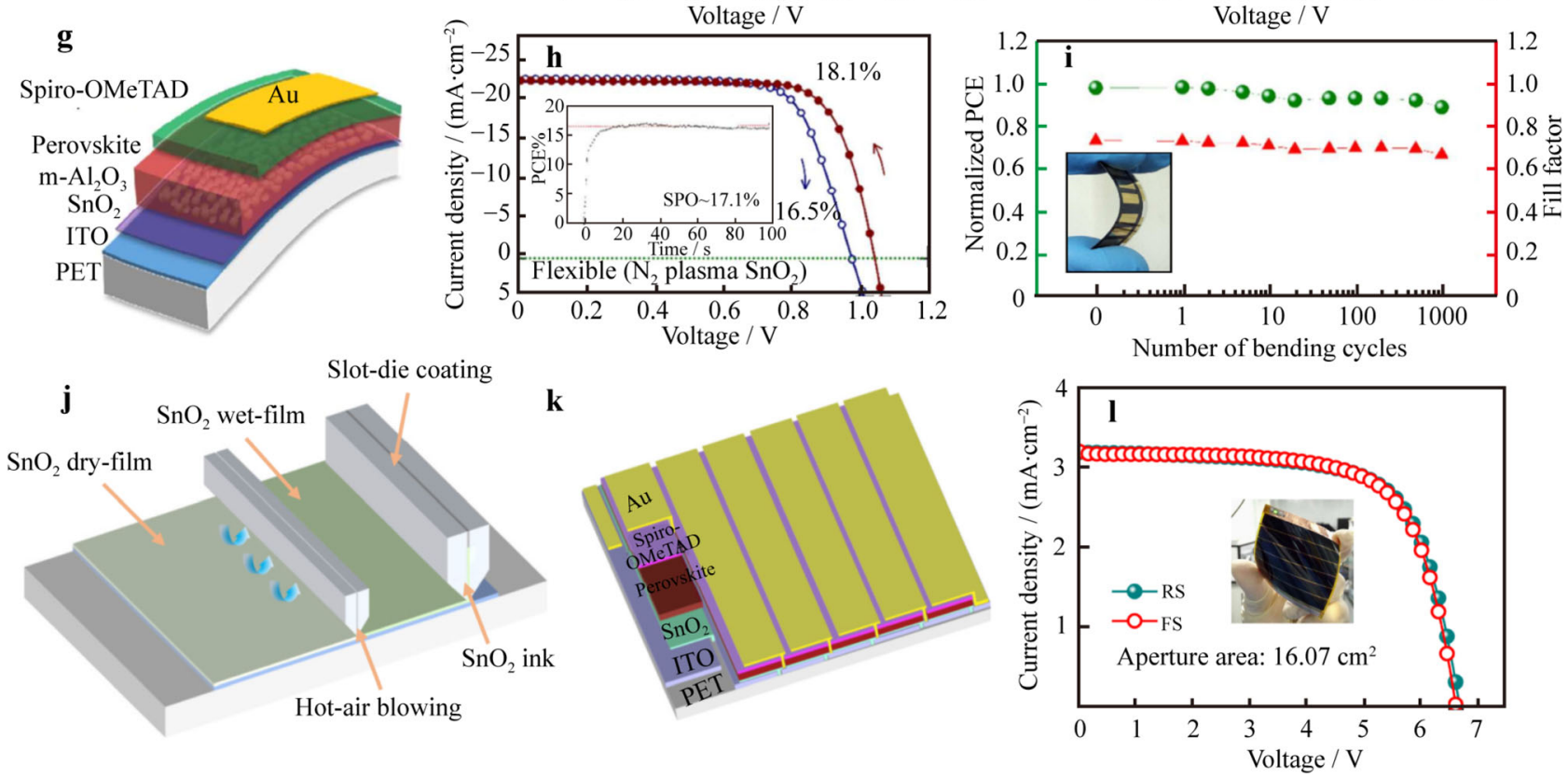

Fig. $7 \mathrm{SEM}$ images of $\mathrm{SnO}_{2}$ deposited by various methods. a $\mathrm{SnO}_{2}$ films coated on FTO substrate with a thermal decomposition method. Reproduced with permission from Ref. [63]. Copyright 2015, American Chemical Society. b $\mathrm{SnO}_{2}$ films coated on FTO by ALD; c SnO films coated on FTO substrate by spin-coating and CBD method. Reproduced with permission from Ref. [110]. Copyright 2016, Royal Society of Chemistry. d SEM image of perovskite film with observable white phase of $\mathrm{PbI}_{2}$ formed on surface; e, $\mathbf{f} J$ - $V$ curves for best devices based on $\mathrm{SnO}_{2}$ NPs in small and large size. Reproduced with permission from Ref. [103]. Copyright 2017, John Wiley and Sons. g Device architecture of flexible device based on $\mathrm{SnO}_{2}$ fabricated with $\mathrm{N}_{2} \mathrm{RF}$ plasma; $\mathbf{h} J$-V characteristics of the flexible device with PCE of $18.1 \%$ and a stable power output efficiency of $17.1 \%$ under 1-sun illumination; i normalized device efficiency (green line) and fill factor (red line) of flexible device being subjected to 1000 bending cycles and (inset) photograph of flexible pero-SC. Reproduced with permission from Ref. [101]. Copyright 2018, American Chemical Society. j Schematic of slot-die coating of $\mathrm{SnO}_{2}$ films; $\mathbf{k}$ structure of six sections series connected large-area flexible devices; I corresponding $J-V$ curves of champion flexible pero-SCs and (inset) photograph. Reproduced with permission from Ref. [105]. Copyright 2018, Springer Nature

commercialized $\mathrm{SnO}_{2}$ NP colloidal solution to develop low-temperature-processed ETLs for efficient planar peroSCs. The $\mathrm{SnO}_{2}$ NPs are very uniform with particle sizes around $3-4 \mathrm{~nm}$, and it can form a dense, pinhole-free film [102]. With the introduction of a $\mathrm{PbI}_{2}$ passivation phase in the perovskite layer, a certificated device efficiency of $19.9 \%$ was acquired. Later on, by further optimizing the $\mathrm{PbI}_{2}$ contents, planar pero-SCs behaved efficiencies of $21.6 \%$ in small size $\left(0.0737 \mathrm{~cm}^{2}\right)$ and $20.1 \%$ in large size $\left(1 \mathrm{~cm}^{2}\right)$ with a certificated PCE of $20.9 \%$ for small size 
device (Fig. 7d-f) [103]. In 2019, the same group reported the use of PEAI for perovskite surface defect passivation, which led to higher-efficiency pero-SCs by passivating the defects and suppressing non-radiative recombination. Planar pero-SCs showed a certificated PCE of $23.32 \%$ with a $V_{\text {oc }}$ as high as $1.18 \mathrm{~V}$ [104]. To investigate the solution printability of $\mathrm{SnO}_{2}$ NPs on plastic substrates, Bu et al. [105] demonstrated a slot-die method for printing highquality $\mathrm{SnO}_{2}$ films for efficient flexible pero-SCs. To suppress the inherent hysteresis caused by $\mathrm{SnO}_{2}$, a universal potassium passivation strategy was conducted to passivate the interface. The small size flexible pero-SCs achieved a PCE of $17.18 \%$ and large-size $(5 \mathrm{~cm} \times 6 \mathrm{~cm})$ flexible modules obtained an efficiency over $15 \%$ with no hysteresis (Fig. 7j-1). Besides commercial $\mathrm{SnO}_{2}$ colloidal NPs, $\mathrm{SnO}_{2}$ quantum dots synthesized by Yang et al. [106] are other promising candidates. Through a facile stirring of $\mathrm{SnCl}_{2} \cdot 2 \mathrm{H}_{2} \mathrm{O}$ and thiourea in ambient air, high-quality $\mathrm{SnO}_{2}$ quantum dots with tunable carrier concentration can be developed. A champion stabilized PCE of $20.32 \%$ on rigid FTO and $16.97 \%$ on flexible PEN were realized for regular pero-SCs.

Similar to $\mathrm{TiO}_{2}$ and $\mathrm{ZnO}$, ALD method is also used to produce $\mathrm{SnO}_{2}$ film. Baena et al. [107] adopted ALD process to produce compact $\mathrm{SnO}_{2}$ films, which showed a more favorable aligned energy level with perovskite film. The resultant pero-SCs exhibited a hysteresis-free behavior with a PCE of $18 \%$ and a high $V_{\text {oc }}$ up to $1.19 \mathrm{~V}$. To facilitate the low-temperature large-scale fabrication, Wang et al. [108] employed plasma-enhanced atomic layer deposition (PEALD) to decrease the deposition temperature to below $100{ }^{\circ} \mathrm{C}$. Pero-SCs based on $\mathrm{SnO}_{2}$ films deposited by PEALD delivered PCEs of $19.03 \%$ and $16.80 \%$ on glass and flexible polymer substrates, indicating the potential of low-temperature process. They further assisted the $\mathrm{SnO}_{2}$ film growth by water vapor, which could promote a more complete reaction of organic precursors, thus giving a high-purity $\mathrm{SnO}_{2}$. The flexible pero-SCs based on the obtained $\mathrm{SnO}_{2}$ reached a remarkable PCE of $18.36 \%$ [109].

CBD method was also used to prepare $\mathrm{SnO}_{2}$ films. Anaraki et al. [110] reported a simple SC-CBD method combining spin-coating (SC) and CBD to form the ETL. They first spin-coated a $\mathrm{SnO}_{2}$ seed layer, then $\mathrm{CBD}$ method was used to grow $\mathrm{SnO}_{2}$ layer as a post-treatment on spincoated layers (Fig. 7b, c). The deposited $\mathrm{SnO}_{2}$ layer based on SC-CBD method demonstrated to present efficient hole blocking ability and improved reproducibility. The resultant pero-SCs showed a PCE of $20.7 \%$ under maximum power point (MPP) tracking with a high $V_{\mathrm{oc}}$ of $1.214 \mathrm{~V}$. Bu et al. [111] also adopted CBD method to fabricate $\mathrm{SnO}_{2}$ ETLs. Combining with a novel quadruple-cation perovskite, $\mathrm{K}_{x} \mathrm{Cs}_{0.05}\left(\mathrm{FA}_{0.85} \mathrm{MA}_{0.15}\right)_{0.95} \mathrm{~Pb}\left(\mathrm{I}_{0.85} \mathrm{Br}_{0.15}\right)_{3}$, PCEs of $20.56 \%$ and $15.76 \%$ were achieved for a small size pero$\mathrm{SCs}$ and $6 \mathrm{~cm} \times 6 \mathrm{~cm}$ sub-modules, respectively.

Several other methods such as electrochemical deposition [77], combustion [112], pulsed laser deposition [113], and E-beam evaporation [79] are also developed. Among them, E-beam evaporation seems a good choice since the fabrication of hundreds of $\mathrm{SnO}_{2}$ ETL substrates can be realized at one time, which deserves industrial deployment. By this deposition technique, Fang et al. reported the efficient $\mathrm{SnO}_{2}$-based planar pero-SCs with a best PCE of up to18.2\% without any interface modification [79].

\subsection{Other MO ETLs}

Apart from commonly used $\mathrm{TiO}_{2}, \mathrm{SnO}_{2}$, and $\mathrm{ZnO}$, some other binary MOs can also be explored as ETL materials. Dong et al. [47] prepared $\mathrm{Cr}_{2} \mathrm{O}_{3}$ film by spin-coating $\mathrm{Cr}_{2} \mathrm{O}_{3}$ ink on FTO substrates without post-annealing. The asprepared $\mathrm{Cr}_{2} \mathrm{O}_{3}$ film showed a high optical transmittance and good electron transport. The planar pero-SCs based on $\mathrm{Cr}_{2} \mathrm{O}_{3}$ achieved a PCE of $16.23 \%$. Wang et al. [50] prepared $\mathrm{CeO}_{x}$ films through a simple sol-gel method at $150{ }^{\circ} \mathrm{C}$. After modifying $\mathrm{CeO}_{x}$ with PCBM, a PCE was increased to $17.04 \%$ and showed a superior stability under illumination. $\mathrm{Hu}$ et al. [114] reported solution-processed $\mathrm{CeO}_{x}$ films at $100{ }^{\circ} \mathrm{C}$ to serve as ETLs on top of perovskite. The inverted pero-SCs achieved a PCE of $17.1 \%$ and robust long-term stability under the protection of $\mathrm{CeO}_{x}$. Wang et al. [115] developed a series of niobium-modified tungsten oxides $\mathrm{W}(\mathrm{Nb}) \mathrm{O}_{x}$ on plastic substrates annealed at $120{ }^{\circ} \mathrm{C}$ and room temperature. It can be found that the introduction of $\mathrm{Nb}^{5+}$ can improve the electron-transporting ability, and a good PCE of $15.65 \%$ was achieved on polyethylene naphthalate (PEN) substrates. Feng et al. [45] developed an E-beam evaporated $\mathrm{Nb}_{2} \mathrm{O}_{5}$ as ETL without any post-treatment. The pero-SCs based on $60-\mathrm{nm}$-thick $\mathrm{Nb}_{2} \mathrm{O}_{5}$ exhibited the champion PCEs of $18.59 \%$ and $15.56 \%$ for rigid and flexible devices, respectively. Moreover, the E-beam evaporated $\mathrm{Nb}_{2} \mathrm{O}_{5}$ is beneficial for largearea flexible pero-SCs with comparable $J_{\mathrm{sc}}$ and $V_{\mathrm{oc}}$ values to those of small-area devices, and the PCE loss was mainly caused by an increased series resistance, leading to a reduced FF.

Compared with binary MOs, ternary MOs possess some unique properties, such as high crystallization and full coverage. Moreover, their chemical and physical properties of materials can be fine-tuned by changing the compositions. $\mathrm{Zn}_{2} \mathrm{SnO}_{4}$ is a typical n-type ternary metal oxide. To decrease the processing temperature, Shin et al. [116] used hydrazine to assist the synthesis of $\mathrm{Zn}_{2} \mathrm{SnO}_{4}$ at a low temperature below $100{ }^{\circ} \mathrm{C}$. Based on this $\mathrm{Zn}_{2} \mathrm{SnO}_{4} \mathrm{NPs}$, a PCE of $15.3 \%$ was achieved for flexible regular pero-SCs. They further tailored the energy levels in oxide ETL using 
$\mathrm{Zn}_{2} \mathrm{SnO}_{4}$ NPs and QDs. The energy level-graded ETL formed by sequential deposition of NPs and QDs exhibited a better electron collection and a higher PCE of $16.5 \%$ on flexible substrate [117]. Jung et al. [118] developed amorphous $\mathrm{Zn}_{2} \mathrm{SnO}_{4}$ films with good surface uniformity, high electron mobility, and low charge traps through a solgel method. The resulted pero-SCs delivered a PCE of $20.02 \%$ with improved device stability and hysteresis behavior.

$\mathrm{BaSnO}_{3}$ is a transparent semiconducting perovskite oxide with a large bandgap up to $3.2 \mathrm{eV}$. However, its high processing temperature over $900{ }^{\circ} \mathrm{C}$ greatly limited its application [119]. To solve this problem, Shin et al. [120] developed a superoxide-molecular cluster colloidal solution to deposit La-doped $\mathrm{BaSnO}_{3}$ films below $300{ }^{\circ} \mathrm{C}$. The pero-SCs realized a PCE of $21.2 \%$ and $93 \%$ of the initial efficiency retained after $1000 \mathrm{~h}$ of 1-sun illumination. However, this temperature is still too high to fabricate devices on plastic substrates. Sun et al. [58] synthesized well-dispersed $\mathrm{BaSnO}_{3}$ NPs by a facile peroxide-precipitate route, which enabled the planar device with $n-i-p$ structure to be processed at low temperature of $150{ }^{\circ} \mathrm{C}$ giving a PCE of $10.96 \%$.

To overcome the performance deficiency of single MO material used as ETL, a simple blending strategy by combining two semiconductors with compensated properties was proposed [121]. Wang et al. [122] found the addition of $\mathrm{TiO}_{x}$ to $\mathrm{WO}_{x}$ would raise the Fermi level and suppress the charge recombination in comparison with pure $\mathrm{WO}_{x}$. As a result, the planar regular pero-SCs based on $\mathrm{WT}_{2 / 10}$ (the molar ratio of titanium to tungsten was 2/10) realized a best PCE of $14.47 \%$ by optimizing the MO component fabricated at $150{ }^{\circ} \mathrm{C}$. They also demonstrated that the $\mathrm{WT}_{2 / 10}$ exhibited temperature-insensitive property when employing it as the ETL of pero-SCs, which exhibited a PCE of $13.45 \%$ at $70{ }^{\circ} \mathrm{C}$ and a PCE of $11.56 \%$ at room temperature, respectively. Moreover, Song et al. [123] fabricated a series of $\mathrm{ZnO}-\mathrm{SnO}_{2}$ nanocomposite thin films by simply mixing $\mathrm{ZnO}$ and $\mathrm{SnO}_{2}$ NPs. When selecting the $\mathrm{ZnO}-\mathrm{SnO}_{2}$ with various ratios as ETL, the resultant devices showed an obvious dependence of $J_{\mathrm{sc}}$ and $\mathrm{FF}$ on the $\mathrm{ZnO} / \mathrm{SnO}_{2}$ ratio. With an optimized weight ratio of 2:1, planar pero-SCs exhibited a relatively high PCE of $14.3 \%$. More importantly, $\mathrm{CH}_{3} \mathrm{NH}_{3} \mathrm{PbI}_{3}$ deposited on $\mathrm{ZnO}-\mathrm{SnO}_{2}$ nanocomposite films obtained much-improved thermostability compared to bare $\mathrm{ZnO}$, indicating the effectiveness of blending strategy in tuning the properties of MO ETLs.

\section{Summary and outlook}

Low-temperature-processed MOs have been shown to be very promising candidates as effective ETLs for efficient planar pero-SCs, which can effectively reduce device fabrication cost and be favorable for large-area and flexible solar cells. In this review, the basic properties of various MO materials in terms of mobility, transparency, energy levels, processability, and even stability are clearly clarified and summarized to understand relationship between device performance and MO ETL. Then, commonly used methods for depositing MO ETLs are presented concisely. Finally, recent developments of low-temperature-processed MO ETLs in high-performance planar pero-SCs are comprehensively presented and discussed. It should be pointed out that an ideal MO ETL for high-performance peso-SCs should meet the critical requirements as follows: (1) solution process and excellent film forming ability for low-cost fabrication technologies; (2) suitable energy levels for an effective charge extraction; (3) high mobility for efficient charge transport; and (4) high ambient, chemical, and optical stability for long-term stable pero-SCs. From this perspective, $\mathrm{SnO}_{2}$ with these unique advantages presents promising candidate of MO-based ETL in planar pero-SCs.

Although significant progress has been made in the past decade, further exploration is needed for low-temperatureprocessed MO ETLs. On one hand, to develop new materials used as effective ETLs with high mobility, low surface defects, and proper energy band alignment is a neverending pace. Besides, optimizations of the MOs via universal strategies are effective to tune their chemical, physical, and optoelectronic properties, such as elemental doping, surface modification, composite construction, and bilayer engineering. As a consequence, the pero-SC devices toward higher efficiency and stronger stability can be dramatically promoted. Noticeably, among the various approaches utilized in fabricating MO ETLs, employing nanocrystal solution to directly deposit ETLs is a low-cost and low-energy consumption process. From this view point, the preparation and use of colloidal nanocrystals with excellent crystallinity and tunable optoelectronic properties can be meaningful in forming the low-temperature ETLs of planar pero-SCs. Therefore, the continuous exploration of novel MOs and optimization processes for nanocrystal ETL will provide a crucial element with highefficiency, low-cost, large-area, and flexible devices.

In flexible pero-SCs, the intrinsically brittle characteristics of MOs are one of the major issues affecting the device application. In comparison, organics show the merit of good flexibility. Therefore, blending MOs with functional organic materials may be an effective approach to increase the flexibility of ETL thin films. Especially when there are specific functional groups interacting with MOs, the organic molecules can be firmly adsorbed on MO. Further, the introduction of chemically crosslinked organic materials can transform a fragile MO ETL into a mechanically tough semiconducting composite by the 
formation of organic network framework. Using this strategy, the surface modification of MO ETLs may also play a positive effect in improving the flexibility. In addition, the organic modification can tune the work function, surface energy, and wetting properties of MOs, etc. Given the large number of surface and interface defects of perovskite, the different functional groups such as Lewis acid and base can be introduced into the organic molecules to form various chemical interactions with the perovskite layer, which can passivate the trap states and facilitate the interfacial charge transfer, thus enhancing device performance and reduce the hysteresis.

Overall, we believe that through developing and optimizing the MOs combining with the in-depth understanding of material science, the planar pero-SCs based on lowtemperature MO ETLs will make a huge leap in performance and deserve to be a promising candidate for future commercialization.

Acknowledgments This study was financially supported by the National Natural Science Foundation of China (Nos. 51922074, 22075194, 51673138, and 51820105003), the National Key Research and Development Program of China (No. 2020YFB1506400), the Natural Science Foundation of the Jiangsu Higher Education Institutions of China (No. 20KJA430010), the Tang Scholar, Collaborative Innovation Center of Suzhou Nano Science and Technology, the Fundamental Research Funds for Jiaxing University (Nos. CDN70518005 and CD70519019), Jiaxing Public Welfare Research Program in 2019 (No. 2019AY11007), and the General Scientific Research Project of Education Department of Zhejiang Province (No. Y201942334).

Open Access This article is licensed under a Creative Commons Attribution 4.0 International License, which permits use, sharing, adaptation, distribution and reproduction in any medium or format, as long as you give appropriate credit to the original author(s) and the source, provide a link to the Creative Commons licence, and indicate if changes were made. The images or other third party material in this article are included in the article's Creative Commons licence, unless indicated otherwise in a credit line to the material. If material is not included in the article's Creative Commons licence and your intended use is not permitted by statutory regulation or exceeds the permitted use, you will need to obtain permission directly from the copyright holder. To view a copy of this licence, visit http://creativecommons. org/licenses/by/4.0/.

\section{References}

[1] O'regan B, Grätzel M. A low-cost, high-efficiency solar cell based on dye-sensitized colloidal $\mathrm{TiO}_{2}$ films. Nature. 1991; 353(6346): 737 .

[2] Gur I, Fromer NA, Geier ML, Alivisatos AP. Air-stable all-inorganic nanocrystal solar cells processed from solution. Science. 2005;310(5747):462.

[3] Zeng G, Zhang J, Chen X, Gu H, Li Y, Li Y. Breaking 12\% efficiency in flexible organic solar cells by using a composite electrode. Sci China Chem. 2019;62(7):851.
[4] Jeon NJ, Noh JH, Kim YC, Yang WS, Ryu S, Seok SI. Solvent engineering for high-performance inorganic-organic hybrid perovskite solar cells. Nat Mater. 2014;13(9):897.

[5] Zhang M, Chen Q, Xue R, Zhan Y, Wang C, Lai J, Yang J, Lin $\mathrm{H}$, Yao J, Li Y, Chen L, Li Y. Reconfiguration of interfacial energy band structure for high-performance inverted structure perovskite solar cells. Nat Commun. 2019;10(1):1.

[6] Jiang Q, Ni Z, Xu G, Lin Y, Rudd PN, Xue R, Li Y, Li Y, Gao Y, Huang J. Interfacial molecular doping of metal halide perovskites for highly efficient solar cells. Adv Mater. 2020; 32(31):2001581.

[7] Wehrenfennig C, Eperon GE, Johnston MB, Snaith HJ, Herz LM. High charge carrier mobilities and lifetimes in organolead trihalide perovskites. Adv Mater. 2014;26(10):1584.

[8] Lin Q, Armin A, Nagiri RCR, Burn PL, Meredith P. Electro-optics of perovskite solar cells. Nat Photonics. 2015;9(2): 106.

[9] Dong Q, Fang Y, Shao Y, Mulligan P, Qiu J, Cao L, Huang J. Electron-hole diffusion lengths $>175 \mu \mathrm{m}$ in solution-grown $\mathrm{CH}_{3} \mathrm{NH}_{3} \mathrm{PbI}_{3}$ single crystals. Science. 2015;347(6225):967.

[10] Kojima A, Teshima K, Shirai Y, Miyasaka T. Organometal halide perovskites as visible-light sensitizers for photovoltaic cells. J Am Chem Soc. 2009;131(17):6050.

[11] Kim HS, Lee CR, Im JH, Lee KB, Moehl T, Marchioro A, Moon SJ, Humphry-Baker R, Yum JH, Moser JE, Grätzel M, Park NG. Lead iodide perovskite sensitized all-solid-state submicron thin film mesoscopic solar cell with efficiency exceeding 9\%. Sci Rep. 2012;2:591.

[12] Shin SS, Lee SJ, Seok SI. Metal oxide charge transport layers for efficient and stable perovskite solar cells. Adv Funct Mater. 2019;29(47):1900455.

[13] Docampo P, Ball JM, Darwich M, Eperon GE, Snaith HJ. Efficient organometal trihalide perovskite planar-heterojunction solar cells on flexible polymer substrates. Nat Commun. 2013;4(1):1.

[14] Zhou H, Chen Q, Li G, Luo S, Song TB, Duan HS, Hong Z, You J, Liu Y, Yang Y. Interface engineering of highly efficient perovskite solar cells. Science. 2014;345(6196):542.

[15] Xue R, Zhang M, Luo D, Chen W, Zhu R, Yang Y, Li Y, Li Y. Dopant-free hole transporting materials with supramolecular interactions and reverse diffusion for efficient and modular p-i-n perovskite solar cells. Sci China Chem. 2020;63(7):987.

[16] Liu M, Johnston MB, Snaith HJ. Efficient planar heterojunction perovskite solar cells by vapour deposition. Nature. 2013; 501(7467):395.

[17] Wang JTW, Ball JM, Barea EM, Abate A, Alexander-Webber JA, Huang J, Saliba M, Mora-Sero I, Bisquert J, Snaith HJ, Nicholas RJ. Low-temperature processed electron collection layers of graphene $/ \mathrm{TiO}_{2}$ nanocomposites in thin film perovskite solar cells. Nano Lett. 2014;14(2):724.

[18] Wojciechowski K, Leijtens T, Siprova S, Schlueter C, Hörantner MT, Wang JTW, Li CZ, Jen AKY, Lee TL, Snaith HJ. C60 as an efficient n type compact layer in perovskite solar cells. J Phys Chem Lett. 2015;6(12):2399.

[19] Kuang C, Tang G, Jiu T, Yang H, Liu H, Li B, Luo W, Li X, Zhang W, Lu F, Fang J, Li Y. Highly efficient electron transport obtained by doping PCBM with graphdiyne in planar-heterojunction perovskite solar cells. Nano Lett. 2015; 15(4):2756.

[20] Liu D, Kelly TL. Perovskite solar cells with a planar heterojunction structure prepared using room-temperature solution processing techniques. Nat Photonics. 2014;8(2):133.

[21] Jiang Q, Zhang L, Wang H, Yang X, Meng J, Liu H, Yin Z, Wu J, Zhang X, You J. Enhanced electron extraction using $\mathrm{SnO}_{2}$ 
for high-efficiency planar-structure $\mathrm{HC}\left(\mathrm{NH}_{2}\right)_{2} \mathrm{PbI}_{3}$-based perovskite solar cells. Nat Energy. 2016;2(1):1.

[22] Singh T, Singh J, Miyasaka T. Role of metal oxide electron-transport layer modification on the stability of high performing perovskite solar cells. Chemsuschem. 2016;9(18): 2559.

[23] Haque MA, Sheikh AD, Guan X, Wu T. Metal oxides as efficient charge transporters in perovskite solar cells. Adv Energy Mater. 2017;7(20):1602803.

[24] Zhang P, Wu J, Zhang T, Wang Y, Liu D, Chen H, Ji L, Liu C, Ahmad W, Chen ZD, Li S. Perovskite solar cells with ZnO electron-transporting materials. Adv Mater. 2018;30(3): 1703737.

[25] Zhou Y, Li X, Lin H. To be higher and stronger-metal oxide electron transport materials for perovskite solar cells. Small. 2020;16(15):1902579.

[26] Ouyang D, Huang Z, Choy WC. Solution-processed metal oxide nanocrystals as carrier transport layers in organic and perovskite solar cells. Adv Funct Mater. 2019;29(1):1804660.

[27] Shin SS, Lee SJ, Seok SI. Exploring wide bandgap metal oxides for perovskite solar cells. APL Mater. 2019;7(2): 022401.

[28] Niu G, Guo X, Wang L, Niu G, Guo X, Wang L. Review of recent progress in chemical stability of perovskite solar cells. J Mater Chem A. 2015;3(17):8970.

[29] Aarik J, Aidla A, Sammelselg V, Uustare T, Ritala M, Leskelä M. Characterization of titanium dioxide atomic layer growth from titanium ethoxide and water. Thin Solid Films. 2000; 370(1-2): 163 .

[30] Reyes-Coronado D, Rodríguez-Gattorno G, Espinosa-Pesqueira ME, Cab C, de Coss RD, Oskam G. Phase-pure $\mathrm{TiO}_{2}$ nanoparticles: anatase, brookite and rutile. Nanotechnology. 2008;19(14):145605.

[31] Leijtens T, Eperon GE, Pathak S, Abate A, Lee MM, Snaith HJ. Overcoming ultraviolet light instability of sensitized $\mathrm{TiO}_{2}$ with meso-superstructured organometal tri-halide perovskite solar cells. Nat Commun. 2013;4(1):1.

[32] Seelig EW, Tang B, Yamilov A, Cao H, Chang RP. Effects of post-thermal annealing on the optical constants of $\mathrm{ZnO}$ thin film. J Alloys Compd. 2008;448(1-2):21.

[33] Srikant V, Clarke DR. On the optical band gap of zinc oxide. J Appl Phys. 1998;83(10):5447.

[34] Look DC, Reynolds DC, Sizelove JR, Jones RL, Litton CW, Cantwell G, Harsch WC. Electrical properties of bulk $\mathrm{ZnO}$. Solid State Commu. 1998;105(6):399.

[35] Yang J, Siempelkamp BD, Mosconi E, De Angelis F, Kelly TL. Origin of the thermal instability in $\mathrm{CH}_{3} \mathrm{NH}_{3} \mathrm{PbI}_{3}$ thin films deposited on $\mathrm{ZnO}$. Chem Mater. 2015;27(12):4229.

[36] Jiang Q, Zhang X, You J. $\mathrm{SnO}_{2}$ : a wonderful electron transport layer for perovskite solar cells. Small. 2018;14(31):1801154.

[37] Yang G, Wang C, Lei H, Zheng X, Qin P, Xiong L, Zhao X, Yan Y, Fang G. Interface engineering in planar perovskite solar cells: energy level alignment, perovskite morphology control and high performance achievement. J Mater Chem A. 2017; $5(4): 1658$.

[38] Li Y, Zhao Y, Chen Q, Yang Y, Liu Y, Hong Z, Liu Z, Hsieh Y-T, Meng L, Li Y, Yang Y. Multifunctional fullerene derivative for interface engineering in perovskite solar cells. J Am Chem Soc. 2015;137(49):15540.

[39] Zhou Y, Yang S, Yin X, Han J, Tai M, Zhao X, Chen H, Gu Y, Wang N, Lin $\mathrm{H}$. Enhancing electron transport via graphene quantum $\operatorname{dot} / \mathrm{SnO}_{2}$ composites for efficient and durable flexible perovskite photovoltaics. J Mater Chem A. 2019;7(4):1878.

[40] Lee SM, Choi CS, Choi KC, Lee HC. Low resistive transparent and flexible $\mathrm{ZnO} / \mathrm{Ag} / \mathrm{ZnO} / \mathrm{Ag} / \mathrm{WO}_{3}$ electrode for organic light-emitting diodes. Org Electron. 2012;13(9):1654.
[41] Zheng H, Tachibana Y, Kalantar-Zadeh K. Dye-sensitized solar cells based on $\mathrm{WO}_{3}$. Langmuir. 2010;26(24):19148.

[42] Wang K, Shi Y, Dong Q, Li Y, Wang S, Yu X, Wu M, Ma T. Low-temperature and solution-processed amorphous $\mathrm{WO}_{x}$ as electron-selective layer for perovskite solar cells. J Phys Chem Lett. 2015;6(5):755.

[43] Janninck RF, Whitmore DH. Electrical conduction in nonstoichiometric $\alpha-\mathrm{Nb}_{2} \mathrm{O}_{5}$. J Chem Phys. 1962;37(12):2750.

[44] Ozer N, Chen DG, Lampert CM. Preparation and properties of spin-coated $\mathrm{Nb}_{2} \mathrm{O}_{5}$ films by the sol-gel process for electrochromic applications. Thin Solid Films. 1996;277(1):162.

[45] Feng J, Yang Z, Yang D, Ren X, Zhu X, Jin Z, Zi W, Wei Q, Liu $\mathrm{S}$. E-beam evaporated $\mathrm{Nb}_{2} \mathrm{O}_{5}$ as an effective electron transport layer for large flexible perovskite solar cells. Nano Energy. 2017;36:1.

[46] Crawford JA, Vest RW. Electrical conductivity of single-crystal $\mathrm{Cr}_{2} \mathrm{O}_{3}$. J Appl Phys. 1964;35(8):2413.

[47] Dong J, Wu JH, Jia JB, He X, Lan Z, Fan LQ, Lin JM, Huang ML. Annealing-free $\mathrm{Cr}_{2} \mathrm{O}_{3}$ electron-selective layer for efficient hybrid perovskite solar cells. Chemsuschem. 2018;11(3):619.

[48] Julkarnain M, Hossain J, Sharif KS, Khan KA. Optical properties of thermally evaporated $\mathrm{Cr}_{2} \mathrm{O}_{3}$ thin films. Can J Chem Eng Tech. 2012;3(4):81.

[49] Patsalas PSLS, Logothetidis S, Sygellou L, Kennou S. Structure-dependent electronic properties of nanocrystalline cerium oxide films. Phys Rev B. 2003;68(3):035104.

[50] Wang X, Deng LL, Wang LY, Dai SM, Xing Z, Zhan XX, Lu XZ, Xie SY, Huang RB, Zheng LS. Cerium oxide standing out as an electron transport layer for efficient and stable perovskite solar cells processed at low temperature. J Mater Chem A. 2017;5(4):1706.

[51] Hashimoto T, Yamada T, Yoko T. Third-order nonlinear optical properties of sol-gel derived $\alpha-\mathrm{Fe}_{2} \mathrm{O}_{3}, \gamma-\mathrm{Fe}_{2} \mathrm{O}_{3}$, and $\mathrm{Fe}_{3} \mathrm{O}_{4}$ thin films. J Appl Phys. 1996;80(6):3184.

[52] Hu W, Liu T, Yin X, Liu H, Zhao X, Luo S, Guo Y, Yao Z, Wang J, Wang N, Lin H, Guo Z. Hematite electron-transporting layers for environmentally stable planar perovskite solar cells with enhanced energy conversion and lower hysteresis. J Mater Chem A. 2017;5(4):1434.

[53] Bohn CD, Agrawal AK, Walter EC, Vaudin MD, Herzing AA, Haney PM, Talin AA, Szalai VA. Effect of tin doping on $\alpha-\mathrm{Fe}_{2} \mathrm{O}_{3}$ photoanodes for water splitting. J Phys Chem C. 2012; 116(29):15290.

[54] Young DL, Moutinho H, Yan Y, Coutts TJ. Growth and characterization of radio frequency magnetron sputter-deposited zinc stannate, $\mathrm{Zn}_{2} \mathrm{SnO}_{4}$, thin films. J Appl Phys. 2002; 92(1):310.

[55] Shin SS, Yang WS, Noh JH, Suk JH, Jeon NJ, Park JH, Kim JS, Seong WM, Seok SI. High-performance flexible perovskite solar cells exploiting $\mathrm{Zn}_{2} \mathrm{SnO}_{4}$ prepared in solution below 100 ${ }^{\circ} \mathrm{C}$. Nat Commun. 2015;6(1):1.

[56] Cherrad D, Maouche M, Maamache M, Krache L. Influence of valence electron concentration on elastic, electronic and optical properties of the alkaline-earth tin oxides $\mathrm{A}_{3} \mathrm{SnO}(\mathrm{A}=\mathrm{Ca}, \mathrm{Sr}$ and $\mathrm{Ba}$ ): a comparative study with $\mathrm{ASnO}_{3}$ compounds. Phys B. 2011;406(14):2714.

[57] Galazka Z, Uecker R, Irmscher K, Klimm D, Bertram R, Kwasniewski A, Naumann M, Schewski R, Pietsch M, Juda U, Fiedler A, Albrecht M, Ganschow S, Markurt T, Guguschev C, Bickermann M. Melt growth and properties of bulk $\mathrm{BaSnO}_{3}$ single crystals. J Phys: Condens Matter. 2016;29(7):075701.

[58] Sun C, Guan L, Guo Y, Fang B, Yang J, Duan H, Chen Y, Li $\mathrm{H}$, Liu $\mathrm{H}$. Ternary oxide $\mathrm{BaSnO}_{3}$ nanoparticles as an efficient electron-transporting layer for planar perovskite solar cells. J Alloys Compd. 2017;722:196. 
[59] Yin X, Xu Z, Guo Y, Xu P, He M. Ternary oxides in the $\mathrm{TiO}_{2}-\mathrm{ZnO}$ system as efficient electron-transport layers for perovskite solar cells with efficiency over $15 \%$. ACS Appl Mater Interfaces. 2016;8(43):29580.

[60] Li X, Hao F, Zhao X, Yin X, Yao Z, Guo Y, Shen H, Lin H. Rational design of solution-processed $\mathrm{Ti}-\mathrm{Fe}-\mathrm{O}$ ternary oxides for efficient planar $\mathrm{CH}_{3} \mathrm{NH}_{3} \mathrm{PbI}_{3}$ perovskite solar cells with suppressed hysteresis. ACS Appl Mater Interfaces. 2017;9(40):34833.

[61] Zhao YH, Zhang KC, Wang ZW, Huang P, Zhu K, Li ZD, Li DH, Yuan LG, Zhou Y, Song B. Comprehensive study of sol-gel versus hydrolysis-condensation methods to prepare $\mathrm{ZnO}$ films: electron transport layers in perovskite solar cells. ACS Appl Mater Interfaces. 2017;9(31):26234.

[62] Song J, Bian J, Zheng E, Wang XF, Tian W, Miyasaka T. Efficient and environmentally stable perovskite solar cells based on $\mathrm{ZnO}$ electron collection layer. Chem Lett. 2015;44(5):610.

[63] Ke W, Fang G, Liu Q, Xiong L, Qin P, Tao H, Wang J, Lei H, Li B, Wan J, Yang G, Yan Y. Low-temperature solution-processed tin oxide as an alternative electron transporting layer for efficient perovskite solar cells. J Am Chem Soc. 2015;137(21): 6730 .

[64] Song J, Zheng E, Bian J, Wang XF, Tian W, Sanehira Y, Miyasaka T. Low-temperature $\mathrm{SnO}_{2}$-based electron selective contact for efficient and stable perovskite solar cells. J Mater Chem A. 2015;3(20):10837.

[65] Kim BJ, Kim DH, Lee YY, Shin HW, Han GS, Hong JS, Mahmood K, Ahn TK, Joo YC, Hong KS, Park NG, Lee S, Jung HS. Highly efficient and bending durable perovskite solar cells: toward a wearable power source. Energy Environ Sci. 2015;8(3):916.

[66] Oviroh PO, Akbarzadeh R, Pan D, Coetzee RAM, Jen TC. New development of atomic layer deposition: processes, methods and applications. Sci Technol Adv Mater. 2019;20(1):465.

[67] Lu H, Ma Y, Gu B, Tian W, Li L. Identifying the optimum thickness of electron transport layers for highly efficient perovskite planar solar cells. J Mater Chem A. 2015;3(32):16445.

[68] Dong X, Hu H, Lin B, Ding J, Yuan N. The effect of ALD-ZnO layers on the formation of $\mathrm{CH}_{3} \mathrm{NH}_{3} \mathrm{PbI}_{3}$ with different perovskite precursors and sintering temperatures. Chem Commun. 2014;50(92):14405.

[69] Lee Y, Lee S, Seo G, Paek S, Cho KT, Huckaba AJ, Calizzi M, Choi DW, Park JS, Lee D, Lee HJ, Asiri AM, Nazeeruddin MK. Efficient planar perovskite solar cells using passivated tin oxide as an electron transport layer. Adv Sci. 2018;5(6): 1800130.

[70] Vadivel S, Rajarajan G. Influence of $\mathrm{Cu}$ doping on structural, optical and photocatalytic activity of $\mathrm{SnO}_{2}$ nanostructure thin films. J Mater Sci Mater Electron. 2015;26(8):5863.

[71] Shin DH, Kim ST, Kim JH, Kang HJ, Ahn BT, Kwon H. Study of band structure at the $\mathrm{Zn}(\mathrm{S}, \mathrm{O}, \mathrm{OH}) / \mathrm{Cu}(\mathrm{In}, \mathrm{Ga}) \mathrm{Se}_{2}$ interface via rapid thermal annealing and their effect on the photovoltaic properties. ACS Appl Mater Interfaces. 2013;5(24):12921.

[72] Sun K, Yan C, Liu F, Huang J, Zhou F, Stride JA, Green M, Hao X. Over $9 \%$ efficient kesterite $\mathrm{Cu}_{2} \mathrm{ZnSnS}_{4}$ solar cell fabricated by using $\mathrm{Zn}_{1-x} \mathrm{Cd}_{x} \mathrm{~S}$ buffer layer. Adv Energy Mater. 2016;6(12):1600046.

[73] Liu X, Liu Z, Sun B, Tan X, Ye H, Tu Y, Shi T, Tang Z, Liao G. All low-temperature processed carbon-based planar heterojunction perovskite solar cells employing Mg-doped rutile $\mathrm{TiO}_{2}$ as electron transport layer. Electrochim Acta. 2018; 283:1115.

[74] Kumar MH, Yantara N, Dharani S, Graetzel M, Mhaisalkar S, Boix PP, Mathews N. Flexible, low-temperature, solution processed $\mathrm{ZnO}$-based perovskite solid state solar cells. Chem Commun. 2013;49(94):11089.
[75] Su TS, Hsieh TY, Hong CY, Wei TC. Electrodeposited ultrathin $\mathrm{TiO}_{2}$ blocking layers for efficient perovskite solar cells. Sci Rep. 2015;5:16098.

[76] Zhang J, Pauportè T. Effects of oxide contact layer on the preparation and properties of $\mathrm{CH}_{3} \mathrm{NH}_{3} \mathrm{PbI}_{3}$ for perovskite solar cell application. J Phys Chem C. 2015;119(27):14919.

[77] Chen JY, Chueh CC, Zhu Z, Chen WC, Jen AKY. Low-temperature electrodeposited crystalline $\mathrm{SnO}_{2}$ as an efficient electron-transporting layer for conventional perovskite solar cells. Sol Energy Mater Sol Cells. 2017;164:47.

[78] Yang D, Yang R, Zhang J, Yang Z, Liu SF, Li C. High efficiency flexible perovskite solar cells using superior low temperature $\mathrm{TiO}_{2}$. Energy Environ Sci. 2015;8(11):3208.

[79] Ma J, Zheng X, Lei H, Ke W, Chen C, Chen Z, Yang G, Fang G. Highly efficient and stable planar perovskite solar cells with large-scale manufacture of E-beam evaporated $\mathrm{SnO}_{2}$ toward commercialization. Sol RRL. 2017;1(10):1700118.

[80] Wojciechowski K, Saliba M, Leijtens T, Abate A, Snaith HJ. Sub-150 ${ }^{\circ} \mathrm{C}$ processed meso-superstructured perovskite solar cells with enhanced efficiency. Energy Environ Sci. 2014;7(3): 1142.

[81] Conings B, Baeten L, Jacobs T, Dera R, D’Haen J, Manca J, Boyen HG. An easy-to-fabricate low-temperature $\mathrm{TiO}_{2}$ electron collection layer for high efficiency planar heterojunction perovskite solar cells. APL Mater. 2014;2(8):081505.

[82] Tan H, Jain A, Voznyy O, Lan X, De Arquer FPG, Fan JZ, Quintero-Bermudez R, Yuan M, Zhang B, Zhao Y, Fan F, Li P, Quan LN, Zhao Y, Lu ZH, Yang Z, Hoogland S, Sargent EH. Efficient and stable solution-processed planar perovskite solar cells via contact passivation. Science. 2017;355(6326):722.

[83] Li Q, Zhao Y, Fu R, Zhou W, Zhao Y, Liu X, Yu D, Zhao Q. Efficient perovskite solar cells fabricated through CsCl-enhanced $\mathrm{PbI}_{2}$ precursor via sequential deposition. Adv Mater. 2018;30(40): 1803095 .

[84] Yella A, Heiniger LP, Gao P, Nazeeruddin MK, Grätzel M. Nanocrystalline rutile electron extraction layer enables low temperature solution processed perovskite photovoltaics with 13.7\% efficiency. Nano Lett. 2014;14(5):2591.

[85] Chen C, Cheng Y, Dai Q, Song H. Radio frequency magnetron sputtering deposition of $\mathrm{TiO}_{2}$ thin films and their perovskite solar cell applications. Sci Rep. 2015;5:17684.

[86] Mali SS, Hong CK, Inamdar AI, Im H, Shim SE. Efficient planar n-i-p type heterojunction flexible perovskite solar cells with sputtered $\mathrm{TiO}_{2}$ electron transporting layers. Nanoscale. 2017;9(9):3095.

[87] Hwang K, Jung YS, Heo YJ, Scholes FH, Watkins SE, Subbiah J, Jones DJ, Kim DY, Vak D. Toward large scale roll-to-roll production of fully printed perovskite solar cells. Adv Mater. 2015;27(7):1241.

[88] Zhou H, Shi Y, Wang K, Dong Q, Bai X, Xing Y, Du Y, Ma T. Low-temperature processed and carbon-based $\mathrm{ZnO} /$ $\mathrm{CH}_{3} \mathrm{NH}_{3} \mathrm{PbI}_{3} / \mathrm{C}$ planar heterojunction perovskite solar cells. J Phys Chem C. 2015;119(9):4600.

[89] Song J, Hu W, Wang XF, Chen G, Tian W, Miyasaka T. $\mathrm{HC}\left(\mathrm{NH}_{2}\right)_{2} \mathrm{PbI}_{3}$ as a thermally stable absorber for efficient $\mathrm{ZnO}$ based perovskite solar cells. J Mater Chem A. 2016;4(21):8435.

[90] Song J, Liu L, Wang XF, Chen G, Tian W, Miyasaka T. Highly efficient and stable low-temperature processed $\mathrm{ZnO}$ solar cells with triple cation perovskite absorber. J Mater Chem A. 2017; 5(26): 13439

[91] Guo Y, Kang L, Zhu M, Zhang Y, Li X, Xu P. A strategy toward air-stable and high-performance $\mathrm{ZnO}$-based perovskite solar cells fabricated under ambient conditions. Chem Eng J. 2018;336:732.

[92] Zhou J, Meng X, Zhang X, Tao X, Zhang Z, Hu J, Wang C, Li $\mathrm{Y}$, Yang S. Low-temperature aqueous solution processed $\mathrm{ZnO}$ 
as an electron transporting layer for efficient perovskite solar cells. Mater Chem Front. 2017;1(5):802.

[93] You J, Meng L, Song TB, Guo TF, Yang YM, Chang WH, Zhong Z, Chen H, Zhou H, Chen Q, Liu Y, De Marco N, Yang Y. Improved air stability of perovskite solar cells via solution-processed metal oxide transport layers. Nat Nanotechnol. 2016;11(1):75.

[94] Savva A, Burgués-Ceballos I, Choulis SA. Improved performance and reliability of $\mathrm{p}$-i-n perovskite solar cells via doped metal oxides. Adv Energy Mater. 2016;6(18):1600285.

[95] Lee KM, Chang SH, Wang KH, Chang CM, Cheng HM, Kei CC, Tseng ZL, Wu CG. Thickness effects of ZnO thin film on the performance of tri-iodide perovskite absorber based photovoltaics. Sol Energy. 2015;120:117.

[96] Tseng ZL, Chiang CH, Wu CG. Surface engineering of ZnO thin film for high efficiency planar perovskite solar cells. Sci Rep. 2015;5:13211.

[97] Tseng ZL, Chiang CH, Chang SH, Wu CG. Surface engineering of $\mathrm{ZnO}$ electron transporting layer via $\mathrm{Al}$ doping for high efficiency planar perovskite solar cells. Nano Energy. 2016;28:311.

[98] Lai WC, Lin KW, Guo TF, Chen P, Wang YT. Conversion efficiency improvement of inverted $\mathrm{CH}_{3} \mathrm{NH}_{3} \mathrm{PbI}_{3}$ perovskite solar cells with room temperature sputtered $\mathrm{ZnO}$ by adding the C60 interlayer. Appl Phys Lett. 2015;107(25):114_1.

[99] Zuo L, Guo H, deQuilettes DW, Jariwala S, De Marco N, Dong S, DeBlock R, Ginger DS, Dunn B, Wang M, Yang Y. Polymer-modified halide perovskite films for efficient and stable planar heterojunction solar cells. Sci Adv. 2017;3(8): e1700106.

[100] Dong Q, Shi Y, Zhang C, Wu Y, Wang L. Energetically favored formation of $\mathrm{SnO}_{2}$ nanocrystals as electron transfer layer in perovskite solar cells with high efficiency exceeding 19\%. Nano Energy. 2017;40:336.

[101] Subbiah AS, Mathews N, Mhaisalkar S, Sarkar SK. Novel plasma-assisted low-temperature-processed $\mathrm{SnO}_{2}$ thin films for efficient flexible perovskite photovoltaics. ACS Energy Lett. 2018;3(7):1482.

[102] Jiang Q, Zhang L, Wang H, Yang X, Meng J, Liu H, Yin Z, Wu J, Zhang X, You J. Enhanced electron extraction using $\mathrm{SnO}_{2}$ for high-efficiency planar-structure $\mathrm{HC}\left(\mathrm{NH}_{2}\right)_{2} \mathrm{PbI}_{3}$-based perovskite solar cells. Nat Energy. 2016;2(1):16177.

[103] Jiang Q, Chu Z, Wang P, Yang X, Liu H, Wang Y, Yin Z, Wu J, Zhang X, You J. Planar-structure perovskite solar cells with efficiency beyond 21\%. Adv Mater. 2017;29(46):1703852.

[104] Jiang Q, Zhao Y, Zhang X, Yang X, Chen Y, Chu Z, Ye Q, Li $X$, Yin Z, You J. Surface passivation of perovskite film for efficient solar cells. Nat Photonics. 2019;13(7):460.

[105] Bu T, Li J, Zheng F, Chen W, Wen X, Ku Z, Peng Y, Zhong J, Cheng YB, Huang F. Universal passivation strategy to slot-die printed $\mathrm{SnO}_{2}$ for hysteresis-free efficient flexible perovskite solar module. Nat Commun. 2018;9(1):4609.

[106] Yang G, Chen C, Yao F, Chen Z, Zhang Q, Zheng X, Ma J, Lei H, Qin P, Xiong L, Ke W, Li G, Yan Y, Fang G. Effective carrier-concentration tuning of $\mathrm{SnO}_{2}$ quantum dot electron-selective layers for high-performance planar perovskite solar cells. Adv Mater. 2018;30(14):1706023.

[107] Correa Baena JP, Steier L, Tress W, Saliba M, Neutzner S, Matsui T, Giordano F, Jacobsson TJ, Srimath Kandada AR, Zakeeruddin SM, Petrozza A, Abate A, Nazeeruddin MK, Grätzel M, Hagfeldt A. Highly efficient planar perovskite solar cells through band alignment engineering. Energy Environ Sci. 2015;8(10):2928.

[108] Wang C, Zhao D, Grice CR, Liao W, Yu Y, Cimaroli A, Shrestha N, Roland PJ, Chen J, Yu Z, Liu P, Cheng N, Ellingson RJ, Zhao X, Yan Y. Low-temperature plasma-enhanced atomic layer deposition of tin oxide electron selective layers for highly efficient planar perovskite solar cells. J Mater Chem A. 2016;4(31):12080.

[109] Wang C, Guan L, Zhao D, Yu Y, Grice CR, Song Z, Awni RA, Chen J, Wang J, Zhao X, Yan Y. Water vapor treatment of low-temperature deposited $\mathrm{SnO}_{2}$ electron selective layers for efficient flexible perovskite solar cells. ACS Energy Lett. 2017; 2(9):2118.

[110] Anaraki EH, Kermanpur A, Steier L, Domanski K, Matsui T, Tress W, Saliba M, Abate A, Grätzel M, Hagfeldt A, Correa-Baena JP. Highly efficient and stable planar perovskite solar cells by solution-processed tin oxide. Energy Environ Sci. 2016;9(10):3128.

[111] Bu T, Liu X, Zhou Y, Yi J, Huang X, Luo L, Xiao J, Ku Z, Peng Y, Huang F, Cheng YB, Zhong J. Novel quadruple-cation absorber for universal hysteresis elimination for high efficiency and stable perovskite solar cells. Energy Environ Sci. 2017; 10(12):2509.

[112] Liu X, Tsai KW, Zhu Z, Sun Y, Chueh CC, Jen AKY. A low-temperature, solution processable tin oxide electron-transporting layer prepared by the dual-fuel combustion method for efficient perovskite solar cells. Adv Mater Interfaces. 2016;3(13):1600122.

[113] Chen Z, Yang G, Zheng X, Lei H, Chen C, Ma J, Wang H, Fang G. Bulk heterojunction perovskite solar cells based on room temperature deposited hole-blocking layer: Suppressed hysteresis and flexible photovoltaic application. J Power Sources. 2017;351:123.

[114] Hu T, Xiao S, Yang H, Chen L, Chen Y. Cerium oxide as an efficient electron extraction layer for p-i-n structured perovskite solar cells. Chem Commun. 2018;54(5):471.

[115] Wang K, Shi Y, Gao L, Chi R, Shi K, Guo B, Zhao L, Ma T. $\mathrm{W}(\mathrm{Nb}) \mathrm{O}_{x}$-based efficient flexible perovskite solar cells: from material optimization to working principle. Nano Energy. 2017;31:424.

[116] Shin SS, Yang WS, Noh JH, Suk JH, Jeon NJ, Park JH, Kim JS, Seong WM, Seok SI. High-performance flexible perovskite solar cells exploiting $\mathrm{Zn}_{2} \mathrm{SnO}_{4}$ prepared in solution below 100 ${ }^{\circ} \mathrm{C}$. Nat Commun. 2015;6(1):7410.

[117] Shin SS, Yang WS, Yeom EJ, Lee SJ, Jeon NJ, Joo Y-C, Park IJ, Noh JH, Seok SI. Tailoring of electron-collecting oxide nanoparticulate layer for flexible perovskite solar cells. J Phys Chem Lett. 2016;7(10):1845.

[118] Jung K, Lee J, Im C, Do J, Kim J, Chae WS, Lee MJ. Highly efficient amorphous $\mathrm{Zn}_{2} \mathrm{SnO}_{4}$ electron-selective layers yielding over $20 \%$ efficiency in $\mathrm{FAMAPbI}_{3}$-based planar solar cells. ACS Energy Lett. 2018;3(10):2410.

[119] Zhu L, Ye J, Zhang X, Zheng H, Liu G, Pan X, Dai S. Performance enhancement of perovskite solar cells using a La-doped $\mathrm{BaSnO}_{3}$ electron transport layer. J Mater Chem A. 2017;5(7):3675.

[120] Shin SS, Yeom EJ, Yang WS, Hur S, Kim MG, Im J, Seo J, Noh JH, Seok SI. Colloidally prepared La-doped $\mathrm{BaSnO}_{3}$ electrodes for efficient, photostable perovskite solar cells. Science. 2017;356(6334): 167

[121] Liu S, Chen W, Shen Y, Wang S, Zhang M, Li Y, Li Y. Intermeshing electron transporting layer for efficient and stable $\mathrm{CsPbI}_{2} \mathrm{Br}$ perovskite solar cells with open circuit voltage over 1.3 V. J Mater Chem A. 2020;8(29):14555.

[122] Wang K, Shi Y, Li B, Zhao L, Wang W, Wang X, Bai X, Wang $\mathrm{S}$, Hao C, Ma T. Amorphous inorganic electron-selective layers for efficient perovskite solar cells: feasible strategy towards room-temperature fabrication. Adv Mater. 2016;28(9):1891.

[123] Song J, Zheng E, Wang XF, Tian W, Miyasaka T. Low-temperature-processed $\mathrm{ZnO}-\mathrm{SnO}_{2}$ nanocomposite for efficient planar perovskite solar cells. Sol Energy Mater Sol Cells. 2016;144:623. 


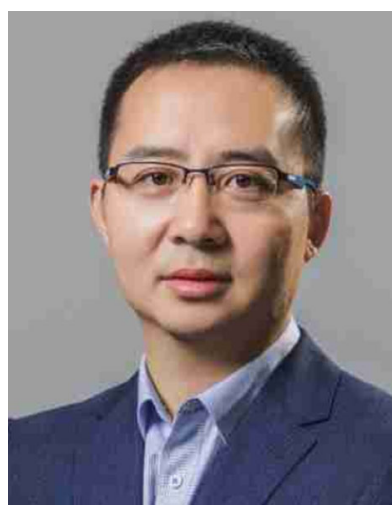

Zai-Fang $\mathbf{L i}$ is a full professor at Jiaxing University. $\mathrm{He}$ received his $\mathrm{Ph} . \mathrm{D}$. degree in Jilin University in 2011. After a postdoctoral training in Huazhong University of Science and Technology, he joined Linkoping University as a postdoctoral research fellow, Marie Curie fellow as well as Vinnova fellow. In 2018, he joined Jiaxing University as a distinguished professor of Nanhu scholars. His research interests mainly focus on perovskite and organic solar cells, especially on the flexible electrodes and devices. He has published over 50 peer-reviewed papers in related fields.

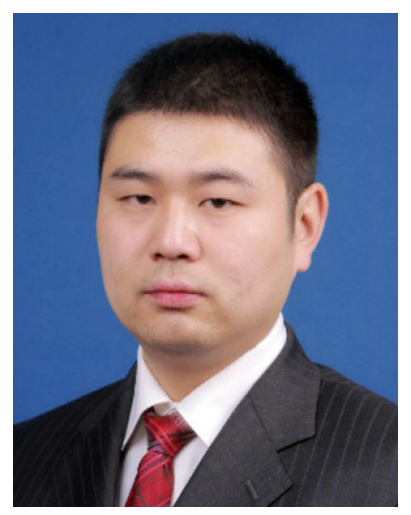

Yao-Wen $\mathbf{L i}$ is a full professor at Soochow University. $\mathrm{He}$ received his Bachelor's and Ph.D. degrees in the Department of Chemistry from Jilin University (2005 and 2010, respectively). In 2011-2014, he collaborated with Prof. Li-Wei Chen as a postdoctoral scientist at SINANO, Chinese Academy of Sciences. Then he joined Prof. Yang Yang's group of UCLA as a visiting scholar. Now, he as the corresponding author has published more than 50 papers in Nat. Commun., Joule, J. Am. Chem. Soc., and Adv. Mater. etc. His present research interests are organic and perovskite materials and devices, and their commercialization technology. 